\begin{tabular}{|l|l|}
\hline $\begin{array}{l}\text { 2. To: (Receiving Organization) } \\
\text { Distribution }\end{array}$ & $\begin{array}{l}\text { 3. From: (Originating Organization) } \\
\text { Nuclear Safety \& Licensing }\end{array}$ \\
\hline $\begin{array}{l}\text { 5. Proj./Prog./Dept./Div.: } \\
\text { Nuclear Safety \& Licensing }\end{array}$ & $\begin{array}{l}\text { 6. Design Authority/Design Agent/Cog. Engr.: } \\
\text { W. H. Grams }\end{array}$ \\
\hline
\end{tabular}

\section{Originator Remarks:}

This document is being released into the supporting document system for retrievability purposes

\section{Receiver Remarks:}

For release

\section{A. Design Baseline Document? $\square$ Yes $\bigotimes$ No}

\section{Related EDT No. \\ N/A \\ 7. Purchase Order No.: \\ $\mathrm{N} / \mathrm{A}$}

9. Equip./Component No.

$\mathrm{N} / \mathrm{A}$

10. System/Bidg./Facility:

$\mathrm{N} / \mathrm{A}$

12. Major Assm. Dwg. No.:

$\mathrm{N} / \mathrm{A}$

13. Permit/Permit Application No.:

$\mathrm{N} / \mathrm{A}$

14. Required Response Date:

\begin{tabular}{|c|c|c|c|c|c|c|c|c|}
\hline 15. & & DATA TR & ANSMITTE & & (F) & (G) & $(\mathrm{H})$ & (I) \\
\hline $\begin{array}{l}\text { (A) } \\
\text { Item } \\
\text { No. }\end{array}$ & (B) Document/Drawing No. & $\begin{array}{l}\text { (C) Sheet } \\
\text { No. }\end{array}$ & (D) Rev. & (E) Title or Description of Data Transmitted & $\begin{array}{l}\text { Approval } \\
\text { Desig- } \\
\text { nator }\end{array}$ & $\begin{array}{c}\text { Reason } \\
\text { for Trans- } \\
\text { mittal }\end{array}$ & $\begin{array}{c}\text { Origi- } \\
\text { nator } \\
\text { Dispo- } \\
\text { stion }\end{array}$ & $\begin{array}{c}\text { Receiv- } \\
\text { er } \\
\text { Dispo- } \\
\text { sition }\end{array}$ \\
\hline & $R P P-6954$ & $\mathrm{~N} / \mathrm{A}$ & 0 & Hazard Evaluation for & $N / A$ & 2 & 1 & 1 \\
\hline & ' & & & a Salt well Centrifugal & & & & \\
\hline & & & & Pump Design Using Service & & & & \\
\hline & & & & Water for Lubrication and & & & & \\
\hline & & & & Cooling & & & & \\
\hline & & & & & & & & \\
\hline & & & & & & & & \\
\hline
\end{tabular}

16.

KEY

\begin{tabular}{|c|c|c|c|c|}
\hline Approval Designator (F) & \multicolumn{2}{|c|}{ Reason for Transmittal (G) } & \multicolumn{2}{|c|}{ Disposition $(\mathrm{H}) \&(\mathrm{I})$} \\
\hline $\begin{array}{l}\text { E, S, Q, D OR N/A } \\
\text { (See WHC-CM-3-5, } \\
\text { Sec. 12.7) }\end{array}$ & $\begin{array}{l}\text { 1. Approval } \\
\text { 2. Release } \\
\text { 3. Information }\end{array}$ & $\begin{array}{l}\text { 4. Review } \\
\text { 5. Post-Review } \\
\text { 6. Dist. (Receipt Acknow. Required) }\end{array}$ & $\begin{array}{l}\text { 1. Approved } \\
\text { 2. Approved w/comment } \\
\text { 3. Disapproved w/comment }\end{array}$ & $\begin{array}{l}\text { 4. Reviewed no/comment } \\
\text { 5. Reviewed w/comment } \\
\text { 6. Receipt acknowledged }\end{array}$ \\
\hline
\end{tabular}

17.

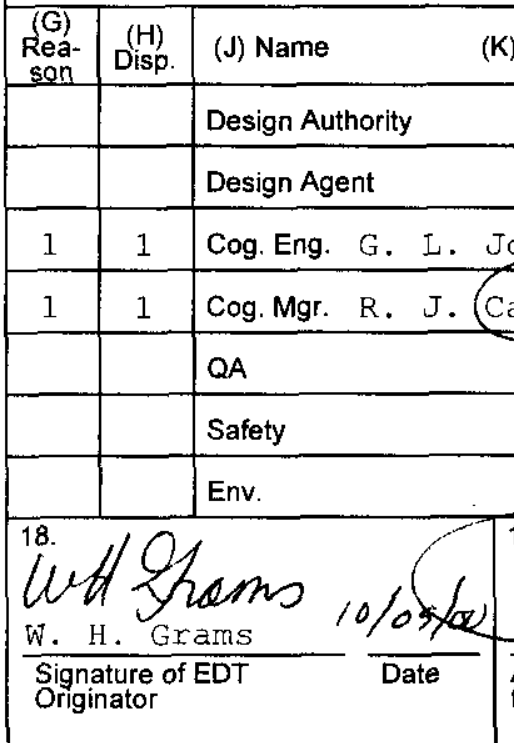

(K) Signature

(L) Date

\begin{tabular}{l|l|c|c} 
(M) MSIN & $\begin{array}{c}\text { Rea- } \\
\text { son }\end{array}$ & $\begin{array}{c}(\mathrm{H}) \\
\text { Disp. }\end{array}$ & (J) Name \\
\hline
\end{tabular}

\section{SIGNATURE/DISTRIBUTION
(See Approval Designator for required signatures)}

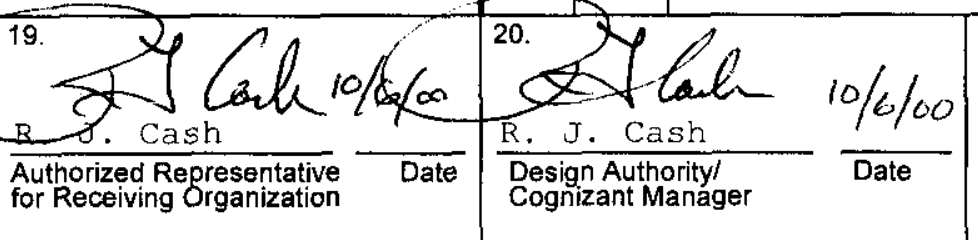

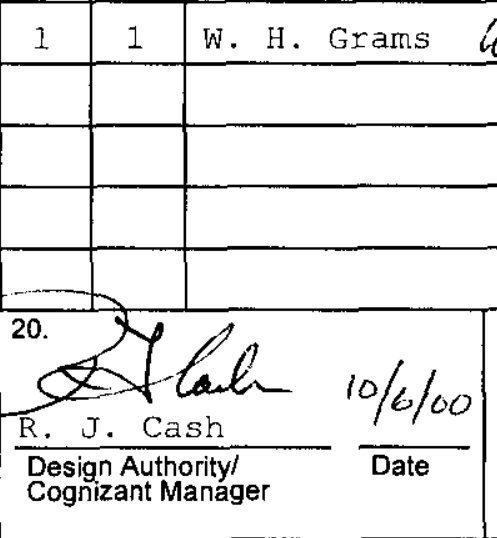

whe hams $10 \%$ slov

21. DOE APPROVAL (if required)

Ctrl No.

$\square$ Approved

$\square$ Approved w/comments

$\square$ Disapproved w/comments 


\section{DISTRIBUTION SHEET}

To

Distribution

Project Title/Work Order

Hazard Evaluation for a Salt Well Centrifugal Pump Design Using

Service water for Lubrication and Cooling, RPP-6954 Rev. 0

\begin{tabular}{|l|l|l}
\hline Tex &
\end{tabular}

Name

CH2M HILL Handford Group, Inc.

J. R. Bellomy

J. B. Billetdeaux

R. J. Cash

W. H. Grams

C. E. Hampton

T. L. Hissong

G. L. Jones

I. E. Kripps

M. R. Koch

J. E. Meacham

G. W. Ryan

D. J. Saueressig

M. V. Shultz

R. D. Smith

W. F. Zuroff

U.S. Department of Energy

office of River Protection

W. Abdul

Y. G. Nooranj
From

Nuclear Safety \& Licensing

MSIN

( 3 hard copies)

$\mathrm{R}-43$

With All

Attach.

Altach.

$\mathrm{X}$

$\mathrm{x}$

$\mathrm{X}$

$\mathrm{X}$

$\mathrm{X}$

$\mathrm{X}$

$\mathrm{X}$

$\mathrm{X}$

$\mathrm{X}$

$\mathrm{x}$

$\mathrm{X}$

$\mathrm{x}$

$\mathrm{x}$

$\mathrm{X}$

$\mathrm{X}$

$\mathrm{X}$ \begin{tabular}{|l} 
Page 1 of 1 \\
Date \\
\hline
\end{tabular}

EDT No. 62514

ECN No. N/A

Attach

Text Only Appendix

Only

EDT/ECN

Only 
RPP-6954

Revision 0

\section{Hazard Evaluation for a Salt Well Centrifugal Pump Design Using Service Water for Lubrication and Cooling}

Prepared for the U.S. Department of Energy

Assistant Secretary for Environmental Management

\section{CH2MHILL \\ Hanford Group, Inc.}

Richland, Washington

Contractor for the U.S. Department of Energy

Office of River Protection under Contract DE-AC06-99RL14047

Approved for public release; further dissemination unlimited 
LEGAL DISCLAIMER

This report was prepared as an account of work sponsored by an agency of the United States Government. Neither the United States Government nor any agency thereof, nor any of their employees, nor any of their contractors, subcontractors or their employees, makes any warranty, express or implied, or assumes any legal liability or responsibility for the accuracy, completeness, or any third party's use or the results of such use of any information, apparatus, product, or process disclosed, or represents that its use would not infringe privately owned rights. Reference herein to any specific commercial product, process, or service by trade name, trademark, manufacturer, or otherwise, does not necessarily constitute or imply its endorsement, recommendation, or favoring by the United States Government or any agency thereof or its contractors or subcontractors. The views and opinions of authors expressed herein do not necessarily state or reflect those of the United States Government or any agency thereof.

This report has been reproduced from the best available copy.

Available in paper copy and microfiche.

Available electronically at http://www.doe.gov/bridge. Available for a processing fee to the U.S. Department of Energy and its contractors, in paper, from:

U.S. Department of Energy

Office of Scientific and Technical Information

P.O. Box 62

Oak Fidge, TN 37831-0062

phone: 865-576-8401

fax: $865-576-5728$

email: reports@adonis.osti.gov(423) 576-8401

Available for sale to the public, in paper, from:

U.S. Department of Commerce

National Technical Information Service

5285 Port Royal Road

Springfield, VA 22161

Phone: 800-553-6847

fax: 703-605-6900

email: orders@ntis.fedworld.gov

online ordering:

http://www.ntis.gov/ordering.htm 
RPP-6954

Revision 0 .

\title{
Hazard Evaluation for a Salt Well Centrifugal Pump Design Using Service Water for Lubrication and Cooling
}

\author{
W. H. Grams
}

CH2M HILL Hanford Group, Inc.

Date Published

October 2000

Prepared for the U.S. Department of Energy

Assistant Secretary for Environmental Management

\section{CH2MHILL Hanford Group, Inc.}

P. O. Box 1500

Richland, Washington

Contractor for the U.S. Department of Energy

Office of River Protection under Contract DE-AC06-99RL14047 


\title{
HAZARD EVALUATION FOR A SALT WELL CENTRIFUGAL PUMP DESIGN USING SERVICE WATER FOR LUBRICATION AND COOLING
}

\author{
W. H. Grams \\ CH2M HILL Handford Group, Inc. \\ Richland, WA 99352 \\ U.S. Department of Energy Contract DE-AC06-96RL13200
EDT/ECN: $625141 \quad$ UC:
Org Code: 7B300 Charge Code: 113187
B\&R Code: $\quad$ Total Pages: 56

Key Words: Hazards, Hazard Analysis, Salt Well Pumping, Pump, Single-Shell. Tanks, Authorization Basis, Tank waste Remediation System, River Protection Project

Abstract: This report documents the results of a preliminary hazard analysis (PHA) covering the new salt well pump design. The PHA identified ten hazardous conditions mapped to four analyzed accidents: flammable gas deflagrations, fire in contaminated area, tank failure due to excessive loads, and waste transfer leaks. This document also presents the results of the control decision/allocation process. A backflow preventer and associated limiting condition were assigned.

TRADEMARK DISCLAIMER. Reference herein to any specific commercial product, process, or service by trade name, trademark, manufacturer, or otherwise, does not necessarily constitute or imply its endorsement, recommendation, or favoring by the United States Government or any agency thereof or its contractors or subcontractors.

Printed in the United States of America. To obtain copies of this document, contact: Document Control Services, P.O. Box 950, Mailstop H6-08, Richland WA 99352, Phone (509) 372-2420; Fax (509) 376-4989.
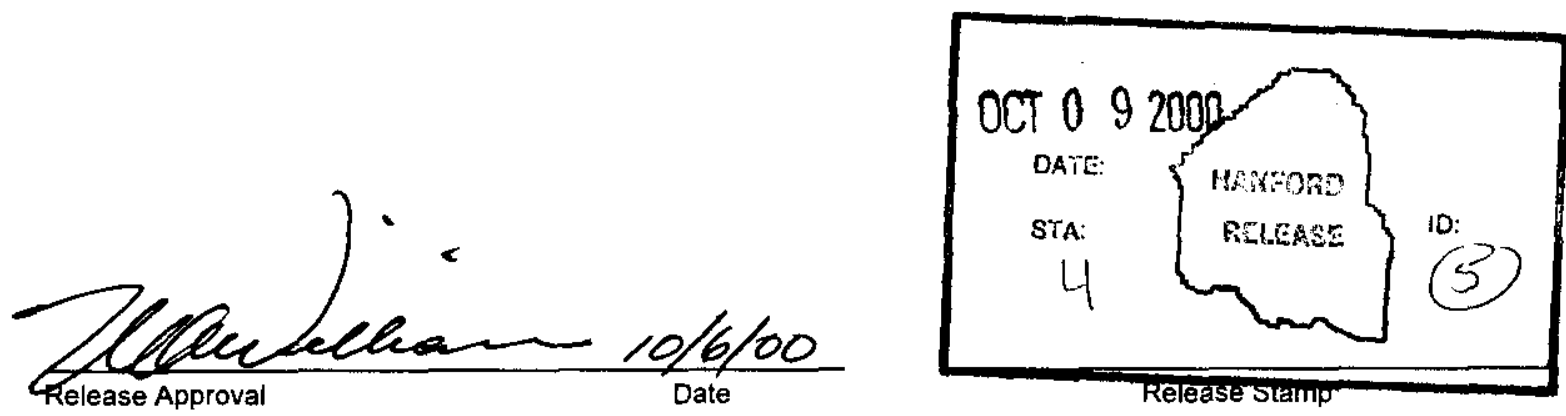

Approved For Public Release 
RPP-6954 REV 0

This page intentionally left blank. 
RPP-6954 REV 0

\section{TABLE OF CONTENTS}

1.0 INTRODUCTION

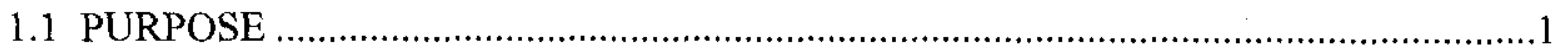

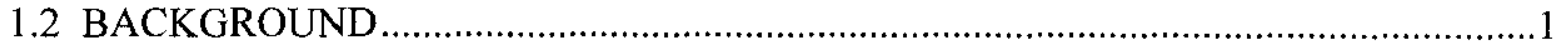

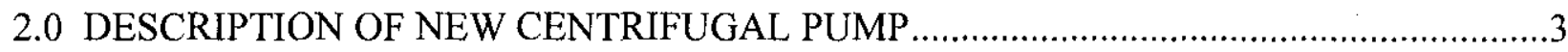

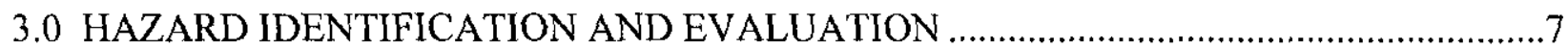

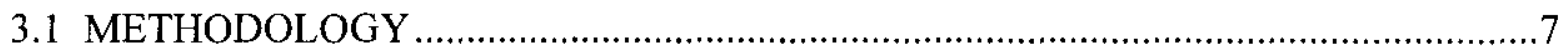

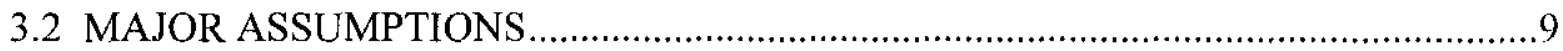

3.3 EVALUATION

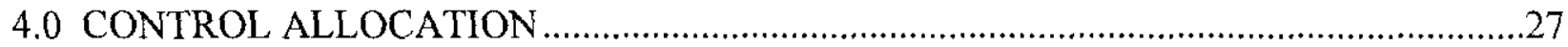

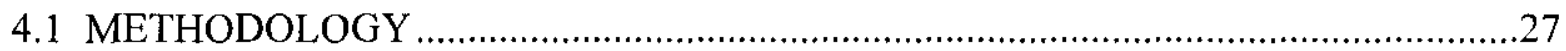

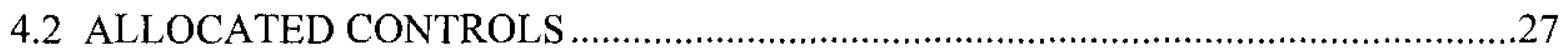

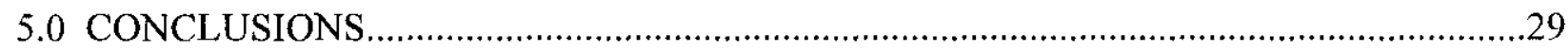

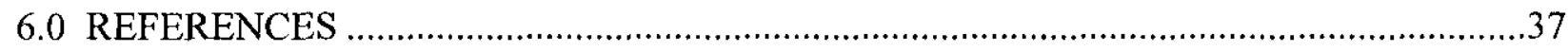

\section{APPENDICES}

A PRELIMINARY HAZARDS ANALYSIS TEAM BIOGRAPHICAL

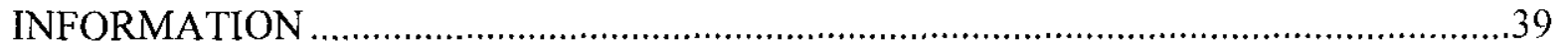

B CONTROL ALLOCATION TEAM BIOGRAPHICAL INFORMATION ……..................43

C PRELIMINARY HAZARDS ANALYSIS AND CONTROL ALLOCATION PEER REVIEW 
RPP-6954 REV 0

TABLES

Table 3.1. Salt Well Pumping New Pump Design Hazardous Conditions as

Initially Identified

Table 3.2. Salt Well Pumping New Pump Design Hazardous Conditions as Amended During Control Allocation.

Table 3.3. Salt Well Pumping New Pump Design Hazardous Conditions Sorted According to Consequence

Table 3.4. New Salt Well Pump Design Hazardous Conditions Mapped to Analyzed Representative Accident

Table 4.1. Control Allocation for the New Salt Well Pump Design Hazardous Conditions.

\section{FIGURES}

Figures 1. P\&ID for New Salt Well Pump .5 


\section{TERMS}

$\begin{array}{ll}\text { AB } & \text { Authorization Basis } \\ \text { AC } & \text { Administrative Control } \\ \text { AIChE } & \text { American Institute of Chemical Engineers } \\ \text { AWF } & \text { aging waste facility } \\ \text { CAM } & \text { Continuous Air Monitor } \\ \text { Cat } & \text { category } \\ \text { Con } & \text { consequence } \\ \text { DCRT } & \text { Double-Contained Receiver Tank } \\ \text { DST } & \text { double-shell tank } \\ \text { Env } & \text { environmental } \\ \text { Freq } & \text { Frequency } \\ \text { FSAR } & \text { Final Safety Analysis Report } \\ \text { gal } & \text { gallon(s) } \\ \text { GRE } & \text { gas release event } \\ \text { Grp } & \text { group } \\ \text { HEPA } & \text { high efficiency particulate air [filter] } \\ \text { hr } & \text { hour } \\ \text { ID } & \text { identification } \\ \text { KPa } & \text { kilopascals } \\ \text { LCO } & \text { Limiting Condition for Operation } \\ \text { MAR } & \text { Material at Risk } \\ \text { Mit } & \text { mitigative } \\ \text { NC } & \text { No Controls } \\ \text { PA } & \text { Pensylvania } \\ \text { P \& ID } & \text { Piping and Instrumentation Diagram } \\ \text { PHA } & \text { Preliminary Hazards Analysis } \\ \text { Prev } & \text { preventive } \\ \text { psig } & \text { pounds per square inch gage } \\ \text { Rep Acc } & \text { representative accident } \\ \text { RPP } & \text { River Protection Project } \\ \text { SS } & \text { stainless steel } \\ \text { SSC } & \text { structures, systems, and components } \\ \text { SST } & \text { single-shell tank } \\ \text { SWP } & \text { salt well pumping } \\ \text { TSR } & \text { Technical Safety Requirement } \\ & \end{array}$


RPP-6954 REV 0

This page intentionally left blank. 
RPP-6954 REV 0

\subsection{INTRODUCTION}

\subsection{PURPOSE}

The River Protection Project (RPP) Authorization Basis (AB) Technical Safety Requirements (TSR) [CHG 2000a] contains controls that address salt well pumping and waste transfers. Currently, the design of salt well pumping (SWP) equipment uses a process lubricated centrifugal pump. The purpose of this document is to record the hazardous conditions identified during the Preliminary Hazards Analysis (PHA) of the new SWP design and to evaluate the relationship to the hazardous conditions currently included in the $\mathrm{AB}$ as documented in the hazard analysis database (CHG 2000b). Also provided in this document is a description of the process and the results of the subsequent control decision/allocation meetings.

This document is not intended to authorize the activity. It documents the results of the hazard identification process and subsequent control decision process as defined in the $\mathrm{AB}$. The hazard identification/evaluation process is used to determine the adequacy of controls and whether the proposed activity is within the $\mathrm{AB}$. This hazard evaluation does not constitute an accident analysis.

\subsection{BACKGROUND}

The SWP process uses an integral motor/centrifugal pump and separate jet pump (foot valve). The motive power for the pumping process is provided by a centrifugal pump/induction motor unit that is located on top of the salt well screen assembly in an single-shell waste tank pump pit. The pump and motor assembly, as currently procured for SWP, is rated for, or otherwise qualifies for, service in Ignition Control Set 2 environments. The current design uses a series G, Chempump manufactured by the Chempump Division of Crane Pumps and Systems, Inc., Warrington, PA. This pump design is process fluid lubricated and cooled; i.e., the salt well liquid is circulated through the pump/motor to provide both lubrication and cooling. Recent SWP operations have been hampered by problems with this design. During SWP operations, the jet pump, foot valve, or other equipment may be clogged with salt crystals or other debris. One method of restarting pump flow is to place the SWP system into recirculation mode and then flush with a clean caustic solution. A recent attempt to restart flow using a caustic flush resulted in hydrogen gas being generated from the caustic reacting with internal aluminum components of the rotor. It was determined that waste salt crystallization in the pump caused a hydraulic imbalance allowing the rotor to exert significant force on the axial thrust surfaces. A hole wore through the stainless steel rotor canister end cap allowing the caustic solution to come in contact with the aluminum which generated aluminum hydroxide and hydrogen gas. This was detected when pump pressure increased without the pump running. To remedy this situation the motor was locked out and the gas was allowed to bleed back to the tank. The new SWP centrifugal pump design addresses these problems. 
RPP-6954 REV 0

This page intentionally left blank. 


\subsection{DESCRIPTION OF NEW CENTRIFUGAL PUMP}

The replacement pump system utilizes a canned rotor pump which is specifically designed to pump waste slurry. A piping and instrumentation diagram is shown in Figure 1 indicating equipment that changed from the previous design.

The new pumping system utilizes heated filtered water as bearing lubrication and motor cooling. The existing SWP dilution system is used to provide a source of heated, filtered water to the new design pump. Upgrades to the dilution system include adding a new design pump with a similar metering pump capable of developing higher pressures, and installation of a raw water filtering system upstream of the dilution tank to provide clean water to the new salt well pump. Additional instrumentation to support operation of the new salt well pump includes a remote bearing monitor, a pump power monitor, and stator winding resistance temperature detectors. A backflow preventer is installed to prevent backflow of tank waste into the pump flush water supply (service water system).

The following are the design attributes that were specifically evaluated in the hazard identification process:

The pump rotor has aluminum components and is fully encapsulated in stainless steel (SS);

- The pump includes thrust washers which prevent shaft bearings from contacting the rotor can in the event of a thrust imbalance;

- The pump is cooled and lubricated with heated and filtered service water;

- The cooling fluid exits into the waste stream through the pump motor front bearing;

- The cooling water metering pump is capable of delivering 318 liters/hour ( $84 \mathrm{gal} / \mathrm{hr}$ ) with normal injection rates of 1.14 to 2.27 liters/hour $(0.3$ to $0.6 \mathrm{gal} / \mathrm{hr})$;

- The cooling water supply from the filter skid to the backflow preventer is SS, heat traced hard piping;

- The cooling line from the exit of the backflow preventer/back pressure valve assemble to the pump is flexible hose; and

- A relief valve is installed downstream of the new metering pump set to relieve at $1206 \mathrm{kPa}$ (175 psig). 
RPP-6954 REV 0

This page intentionally left blank. 
Figure 1. Piping and Instrument Diagram for New Salt Well Pump.

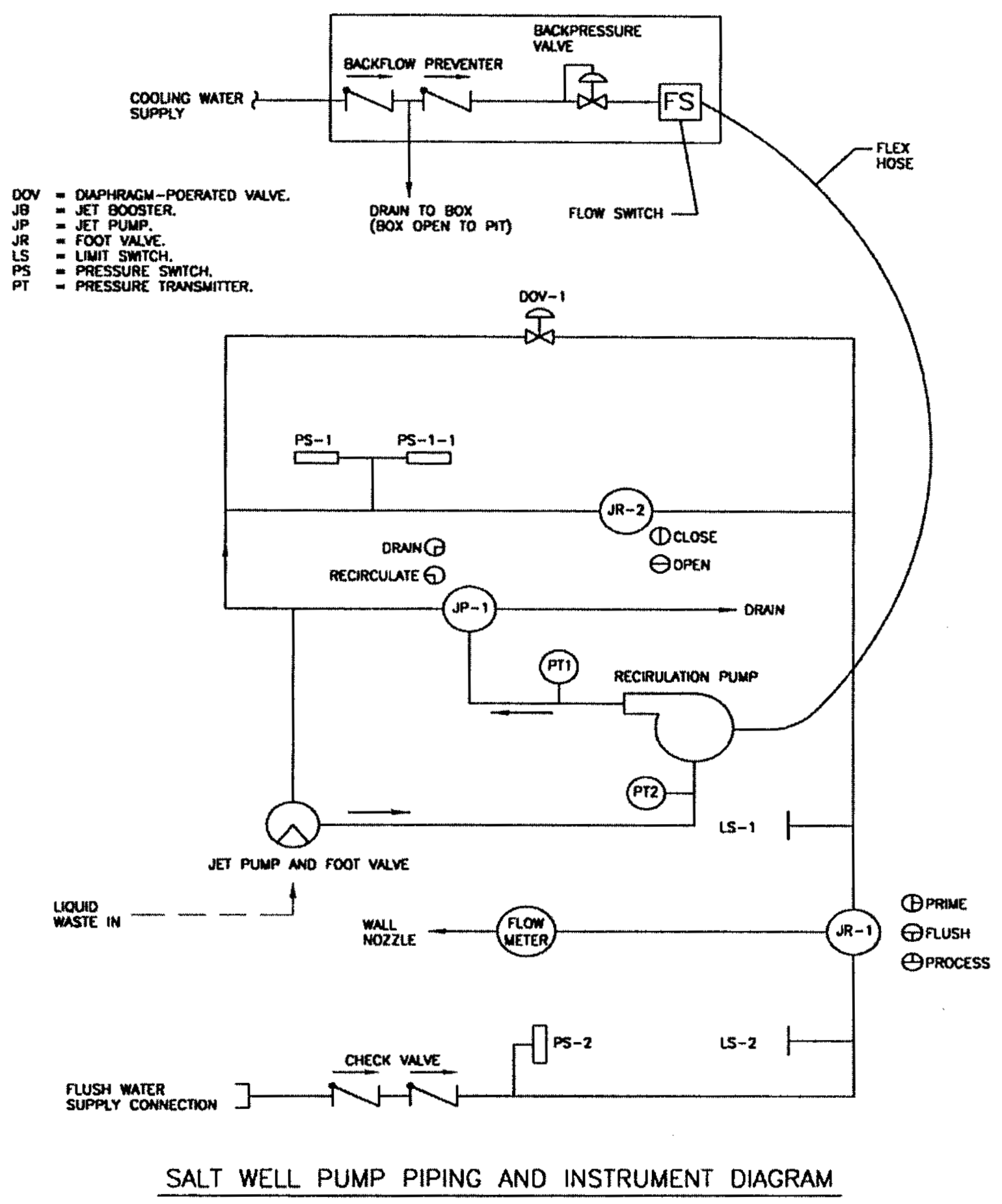


RPP-6954 REV 0

This page intentionally left blank. 


\section{RPP-6954 REV 0}

\subsection{HAZARD IDENTIFICATION AND EVALUATION}

The hazards identification and evaluation of the new process water cooled and lubricated pump design for SWP used the Preliminary Hazards Analysis (PHA) method. The PHA consisted of a systematic brainstorming process which included the following:

- Postulating hazards associated with the new pump design;

- Estimating the frequencies and consequences of the hazardous conditions; and

- Identifying the possible mitigative and preventive measures for each postulated hazardous condition.

The American Institute of Chemical Engineers in their publication "Guidelines for Hazard Evaluation Procedures," (AIChE 1992) recognizes the PHA process as a creditable method of hazard evaluation. A multi-disciplinary team records the results of this brainstorming process using a tabular format. The depth of the PHA is directly related to the experience and knowledge of the participants. A short resume of each team member is included in Appendix A to document the experience and knowledge of the PHA team.

\subsection{METHODOLOGY}

The PHA team met to develop the raw data. The information was recorded systematically in tabular format. The following sections describe the PHA table structure and details for recording information. The PHA was structured to ensure a systematic and thorough evaluation of the potential hazards. The PHA captured the following information:

- Item ID: The item identification (ID); used to record a unique identifier for the hazardous condition.

- Location/Activity: Specific point in the system or process where the deviation from the desired condition of a process variable is evaluated.

- Hazardous Condition: The hardware failures, operational faults, or conditions that could result in undesired consequences during waste transfer activities.

- Candidate Causes: The causes leading to the Hazardous Condition. Identifying causes is important when determining potential existing engineering and administrative features for significant hazardous conditions as well as potential consequences. In many cases, multiple hardware or operational faults are required to produce a hazardous condition. This column identifies the sequence of hardware and operational faults required to produce the postulated hazardous condition.

- Material at Risk: The material which could be released in an associated accident.

- Immediate Consequence: The potential consequences that could result from the postulated hazardous condition. 
- Engineered Safety Features: Existing engineered features (hardware items) identified by the PHA team that have the potential to mitigate or prevent the hazardous condition of concern. The engineered features are candidates for designation as Safety-Significant items for hazardous conditions that pose a significant threat to the health of facility workers and onsite personnel or Safety-Class for hazards that pose a significant threat to offsite individuals. These items should not be construed as being the "official" controls that would eventually be credited in the AB.

- Administrative Safety Features: Technical Safety Requirements and other existing controls identified by the PHA team that have the potential to mitigate or prevent the hazardous condition of concern. These items should not be construed as being the "official" administrative features that would eventually be credited in the AB.

- Consequence Category No Controls (Con Cat NC): The consequence ranking is a "first cut," qualitative estimate of the safety severity of the consequences assuming no controls are present. The following system is used:

So Negligible safety concerns for the facility worker.

S1 Potential industrial injury, low radiological dose consequences or chemical exposure to the facility worker.

S2 Potential significant radiological dose consequences or chemical exposure to onsite workers located outside the facility.

S3 Potential significant radiological dose consequences or chemical exposure to the offsite population.

- Frequency Category No Controls (Freq Cat NC): The frequency category is a "first cut," qualitative estimate of the likelihood of the hazardous condition assuming no controls are present. The following system is used:

F3 Events that are expected to occur one or more times during the lifetime of the facility, categorized as "anticipated" events. The frequency range associated with this category is less than $1 \mathrm{E}-02 / \mathrm{yr}$.

F2 Events that could occur during the lifetime of the facility, but with low probability. Such events are categorized as "unlikely" and fall in the range of $1 \mathrm{E}-04 / \mathrm{yr}$ to $1 \mathrm{E}-02 / \mathrm{yr}$.

F1 Events not expected to occur during the lifetime of the facility, categorized as "extremely unlikely." The frequency range associated with this category is $1 \mathrm{E}-06 / \mathrm{yr}$ to $1 \mathrm{E}-04 / \mathrm{yr}$.

F0 Events categorized as "beyond extremely unlikely," with a frequency less than 1E-06/yr. Events in this category (such as a meteor strike) are so unlikely they generally do not require special controls.

- Environmental Category (Env Cat): The environmental consequence ranking is a "first cut," qualitative estimate of the environmental severity of the hazardous condition assuming no controls are present. The following system is used:

E0 No significant environmental effect outside the facility confinement systems.

E1 Limited environmental discharge of hazardous material outside the facility. 
E2 Large environmental discharge of hazardous material within the plant site boundary.

E3 Significant environmental discharges of hazardous material outside the plant site boundary.

- Remarks: Miscellaneous observations or clarifying comments for a given item.

\subsection{MAJOR ASSUMPTIONS}

The following assumptions were used during the hazard identification process:

- A rotor canister breach as well as a backflow of waste or flush solution is required to allow caustic solution to come in contact with aluminum components of the pump.

- The pump design is appropriate for use with tank waste.

- The aluminum/caustic reaction will develop sufficient pressure to cause hydrogen to escape in the recirculation (closed loop) mode.

- Cooling water (filtered service water) is limited to flows from 1.14 to 3.03 liters per minute $(0.3$ to $0.8 \mathrm{gpm})$ by the metering pump

- The cooling water metering pump is capable of a maximum delivery of 318 liters/hour (84 gal/hr).

- The operating pressures, approximately $345 \mathrm{kPa}(50 \mathrm{psi})$ in the volute of the new salt well pump, are sufficient to allow backflow of waste through the cooling water supply line.

- SSTs suitable for salt well pumping are not likely to experience large gas release events.

- The throttle bushing (front near impeller) will restrict flow in the reverse direction.

\subsection{EVALUATION}

Ten hazardous conditions associated with the new SWP pump design were identified by the PHA team. These hazardous conditions are presented in Table 3-1. The table includes the following information: Item ID, Location/Activity, Hazardous Condition, Candidate Cause, Material at Risk, Immediate Consequence, Engineered Safety Features, Administrative Safety Features, Consequence Category No Control, Frequency Category No Control, and remarks. The qualitatively assigned consequence (severity) of the 10 hazardous conditions assigned by the PHA team resulted in the following totals for each consequence category:

0 So, Negligible safety concerns for the facility worker;

1 S1, Potential industrial injury, low radiological dose consequences or chemical exposure to the facility worker;

6 S2, Potential significant radiological dose consequences or chemical exposure to onsite workers located outside the facility; and

3 S3, Potential significant radiological dose consequences or chemical exposure to the offsite population. 
Following the initial PHA deliberations, a control decision/allocation team was impaneled. The control decision/allocation team roster and short resumes are presented in Appendix B. The initial step during the control decision meeting is to review the results of the PHA. This review identified three hazardous conditions where the frequency of occurrence was revised. The changes (see Table 3-1) that resulted from this review are:

- ID\# NEWSWP-01: The frequency changed from F3 to F2 based on the need for multiple failures to initiate the hazardous condition.

- ID\# NEWSWP-02: The frequency changed from F1 to F0 based on additional details of the design which revealed that the re-circulation loop could not be pressurized, eliminating the cause of a piping failure and subsequent release of flammable gas.

- ID\# NEWSWP-10: The frequency changed from F2 to F0 based upon the team consensus that the failure of the backflow preventer, such that waste could leak to the surface, was not credible.

Table 3.2 lists hazardous conditions identified during the PHA as revised by the control allocation team. This listing is further sorted according to consequences in Table 3-3.

Table 3-4 provides a mapping of the hazardous conditions identified for the new SWP design to the analyzed representative accidents as described in the Tank Waste Remediation System Final Safety Analysis Report (FSAR) [CHG 2000c]. The information presented in this table includes the BIN, Item ID, Material at Risk, Hazardous Condition, Cause, Initial Frequency No Controls, Initial Safety Consequence No Controls, Cause Group, and Representative Accident. The information not previously defined is:

- BIN: A code that describes the release attributes for high Safety Consequences (S2 or S3) and Worker (S1) with anticipated frequency (F3) hazardous conditions.

- Cause Group (Cause Grp): - An alpha/numeric code used to permit sorting of data by the cause of the hazardous conditions.

- Representative Accident (Rep Acc): Representative Accident - An alpha/numeric code used to specify the analyzed accident in the FSAR. Only hazardous conditions with high Safety Consequence (S2 or S3) are assigned to representative accidents.

Included with the hazardous conditions identified for the new salt well pump design are the hazardous conditions identified as being represented by the analyzed accident. The breakdown for Table 3-4 shows:

2 hazardous conditions are related to Flammable Gas Deflagrations - SST (Rep Acc 05)

1 hazardous condition is related to Fire in Contaminated Area (Rep Acc 07)

1 hazardous condition is related to Tank Failure Due to Excessive Loads (Rep Acc 12) 


\section{RPP-6954 REV 0}

1 hazardous condition is related to Waste Transfer Leak Into Structure (Rep Acc 33A)

4 hazardous conditions are related to Waste Transfer Leak Due To Misrout (Rep Acc 33D)

There was one hazardous condition related to worker safety (minor exposure or environmental release) that is not mapped to a representative accident. 
RPP-6954 REV 0

This page is intentionally left blank. 
RPP-6954 REV 0

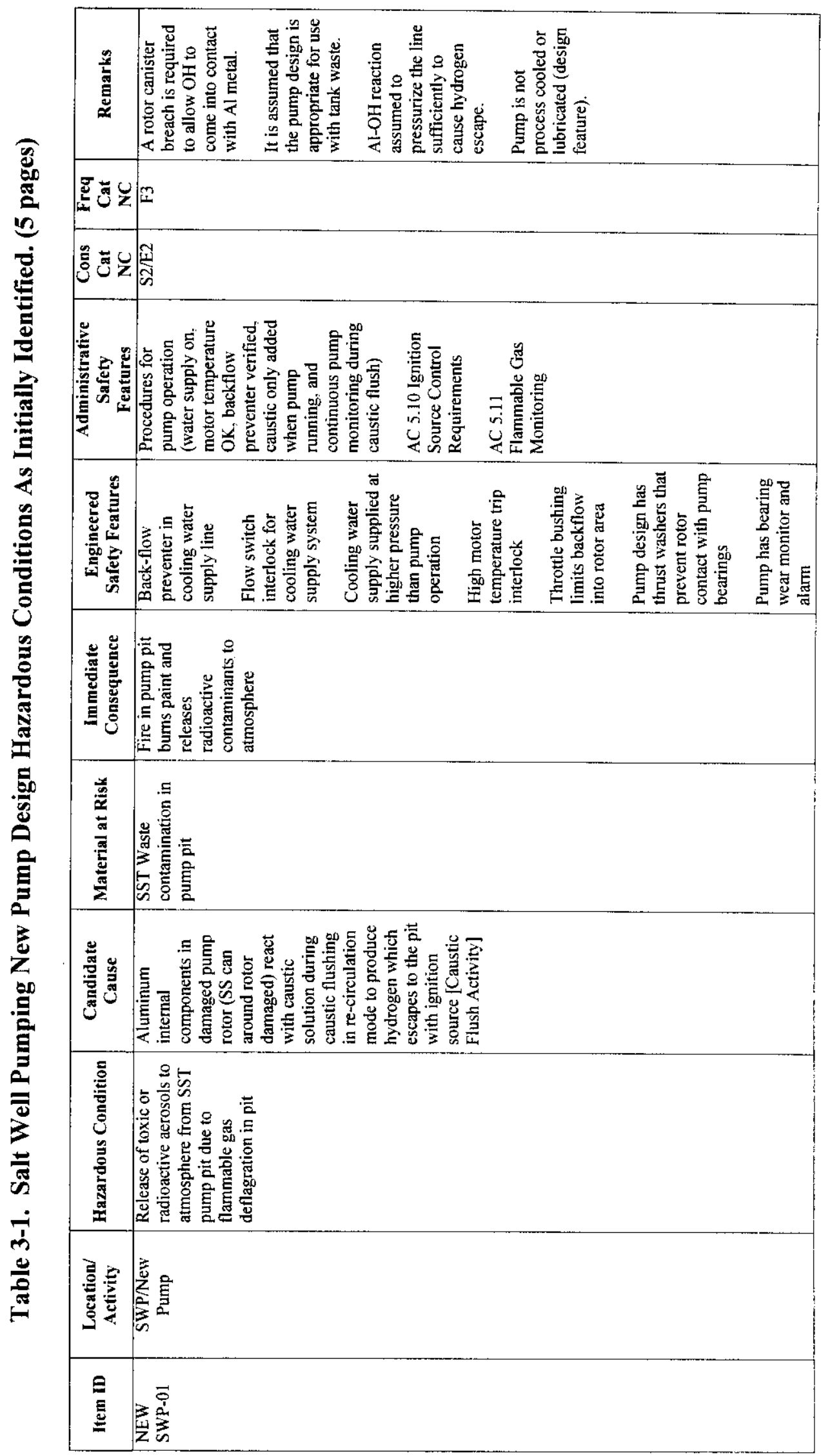




\section{RPP-6954 REV 0}

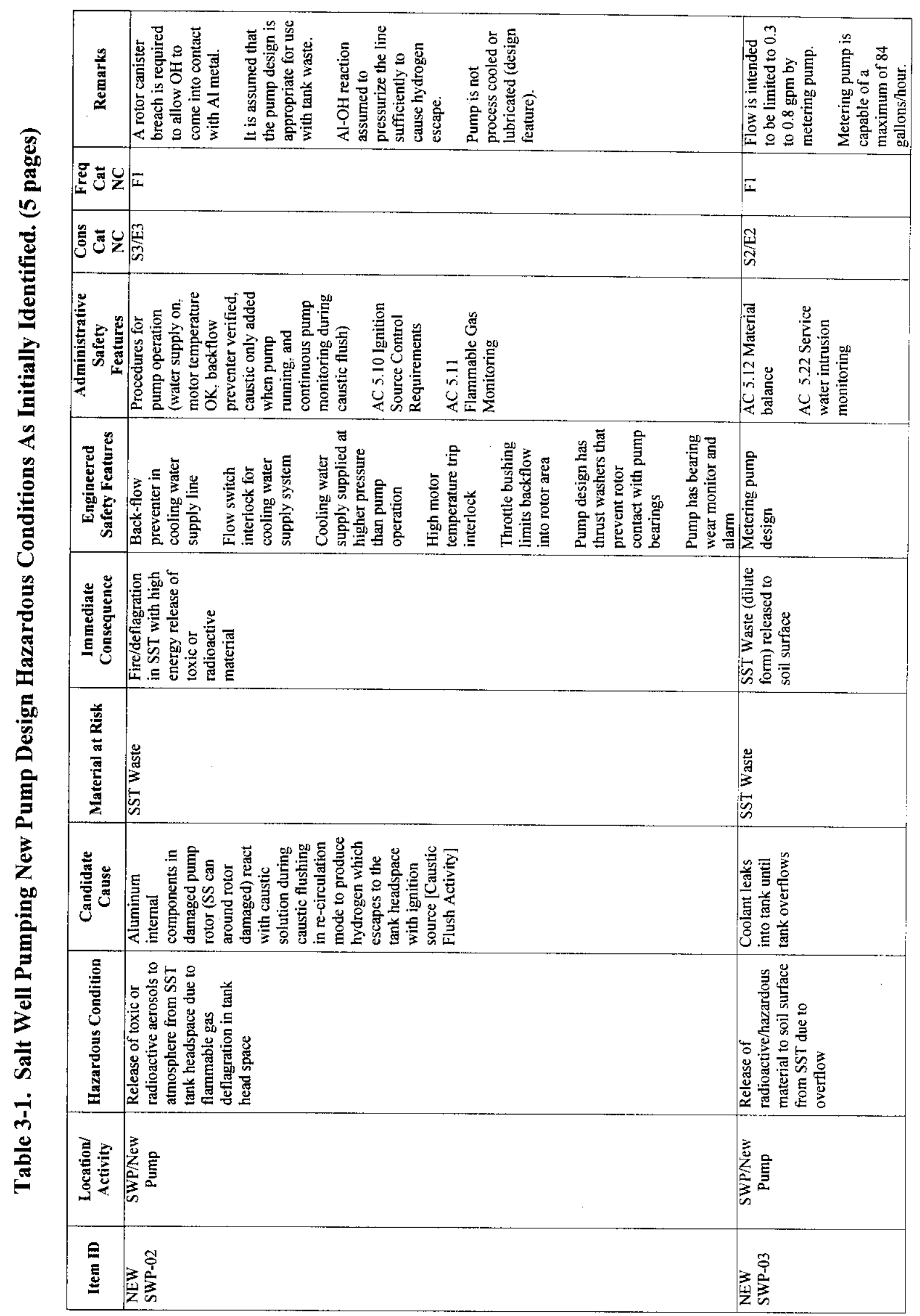


RPP-6954 REV 0

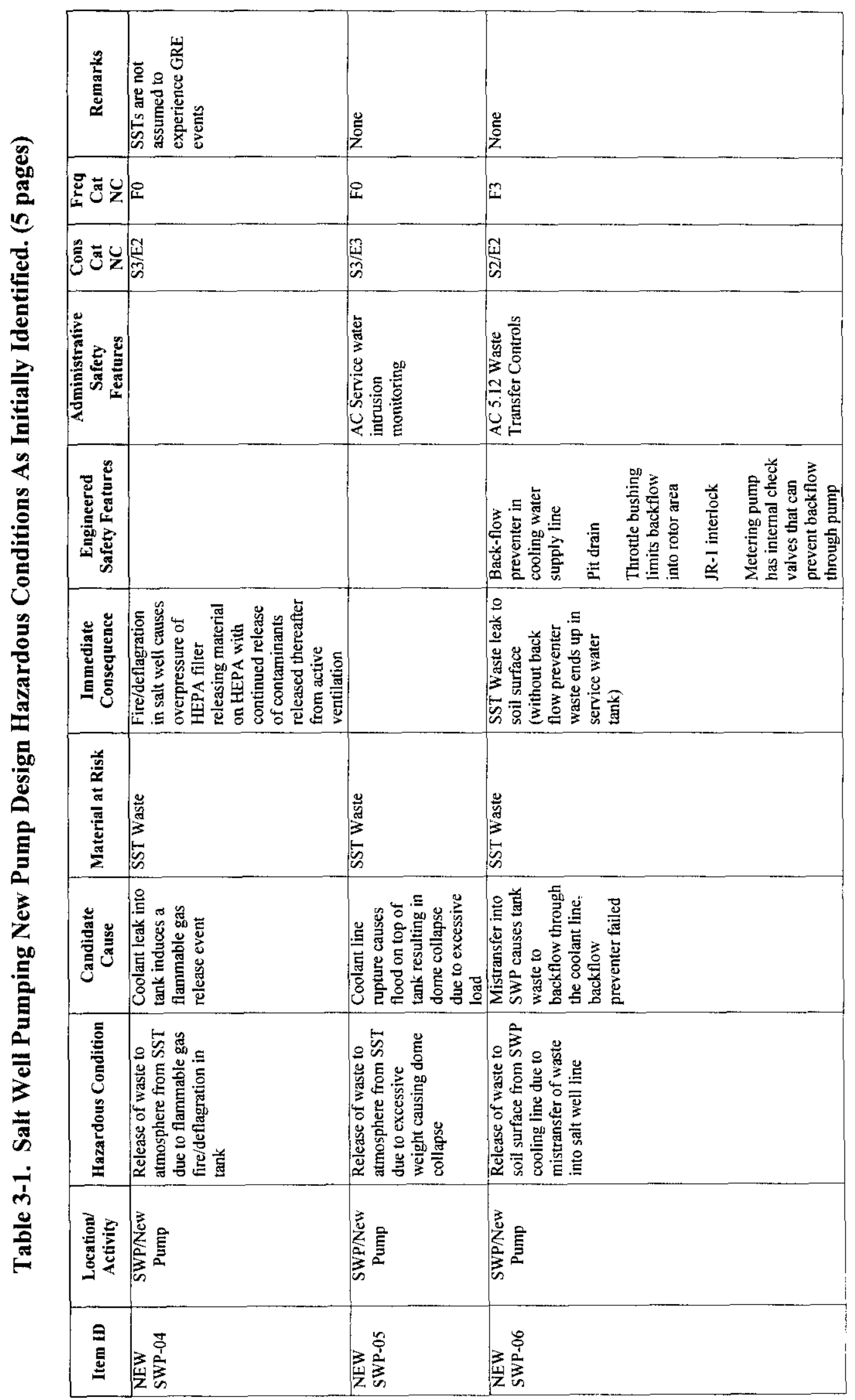




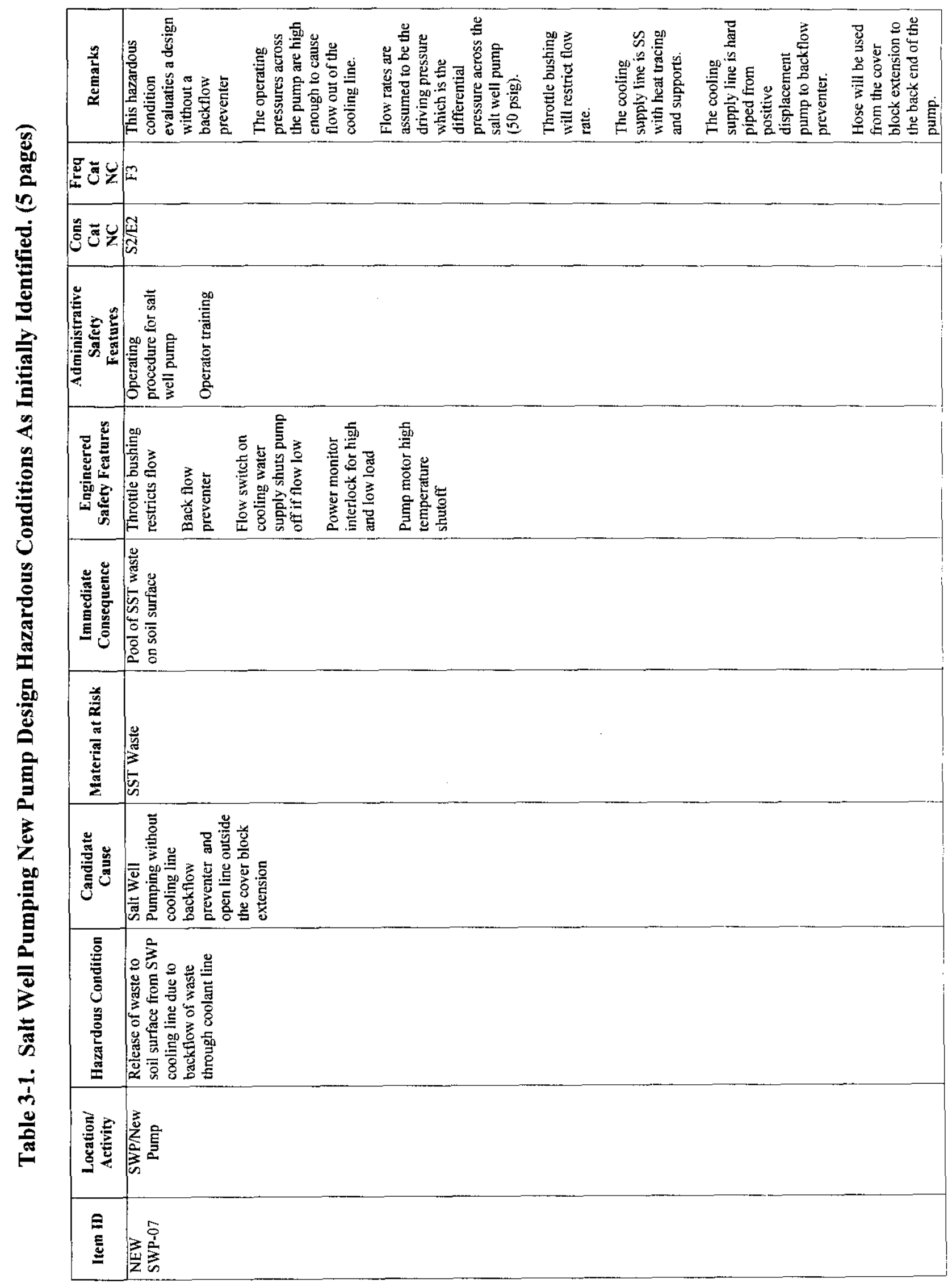


RPP-6954 REV 0

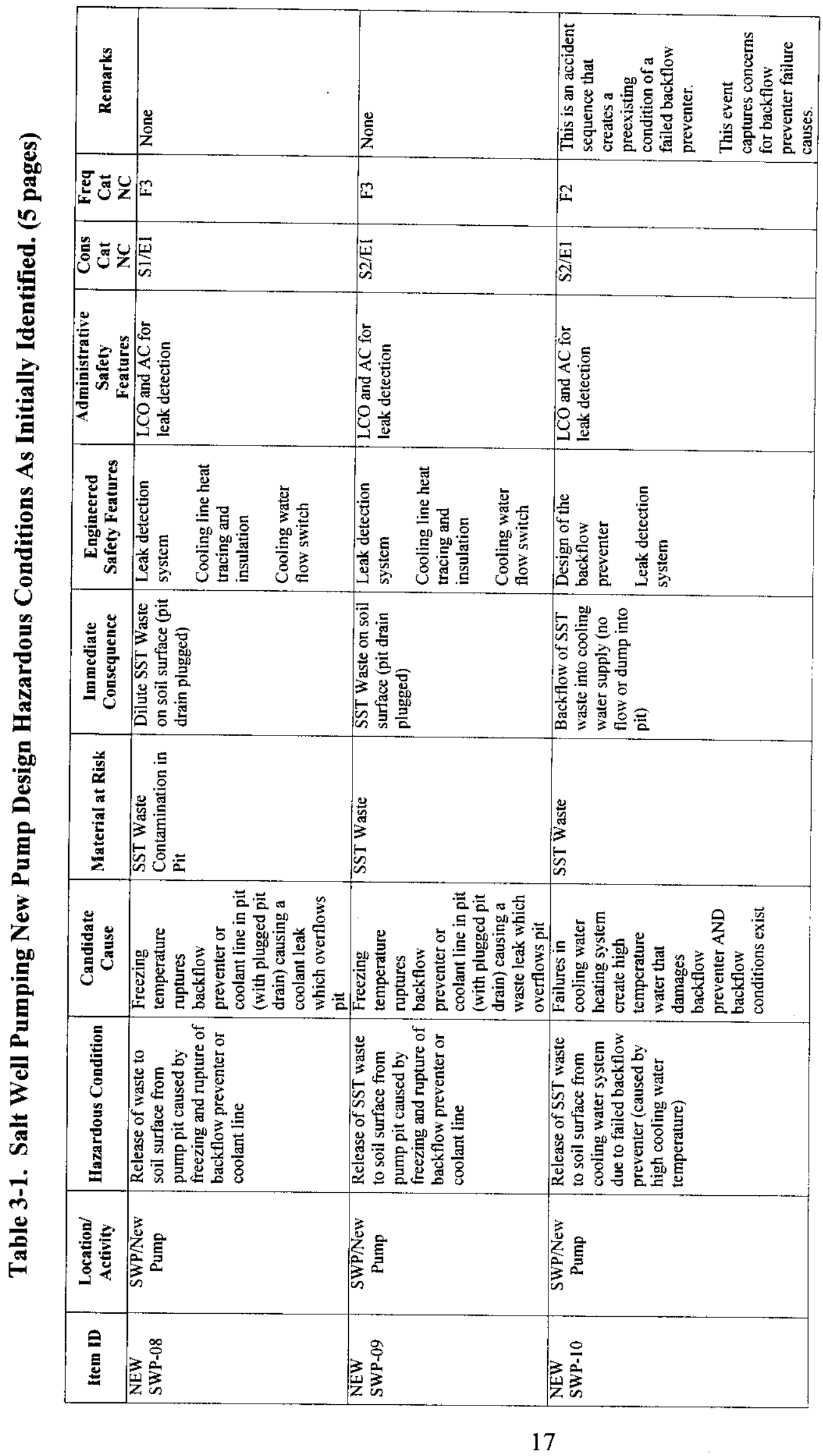




\section{RPP-6954 REV 0}

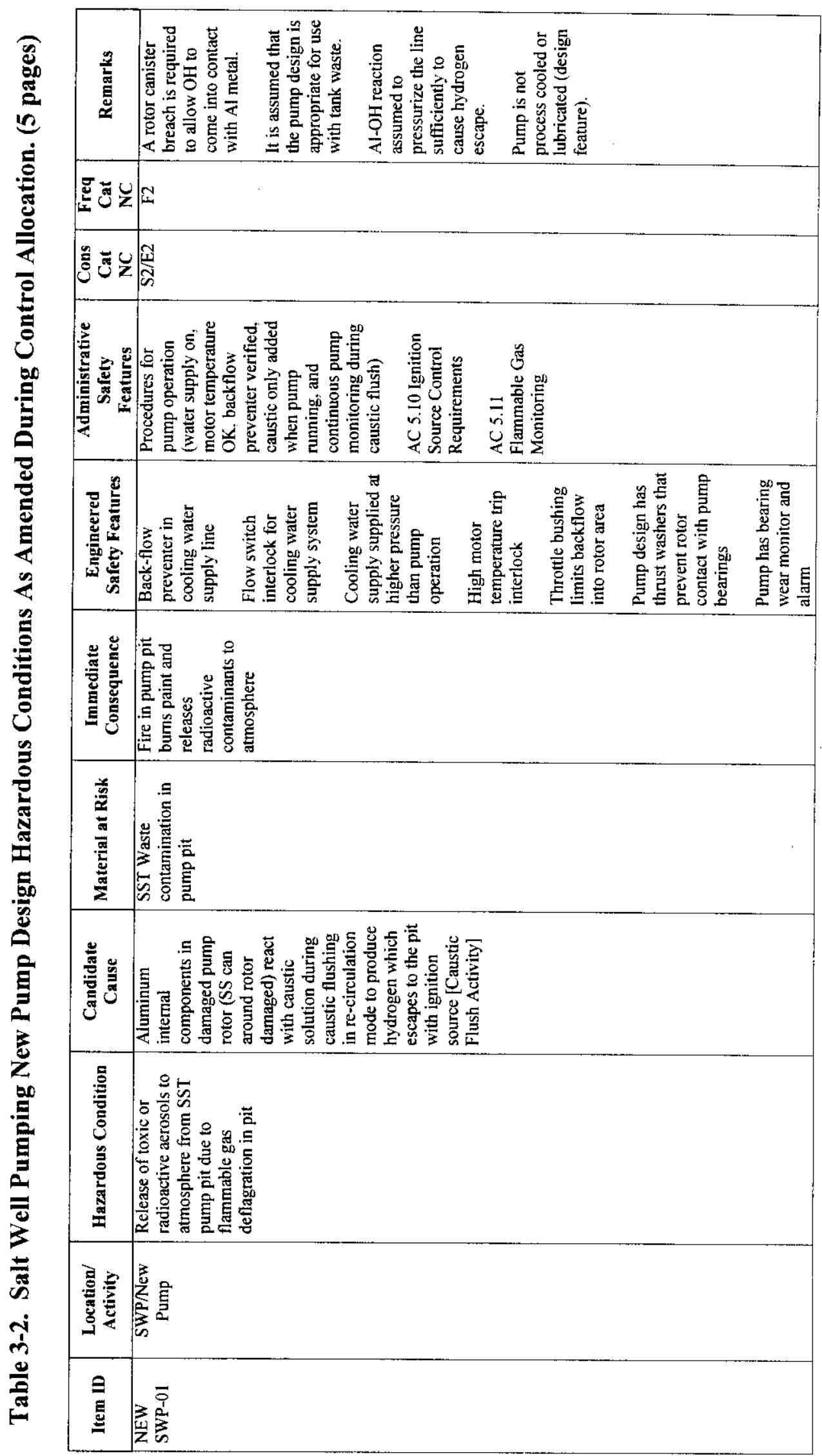




\section{RPP-6954 REV 0}

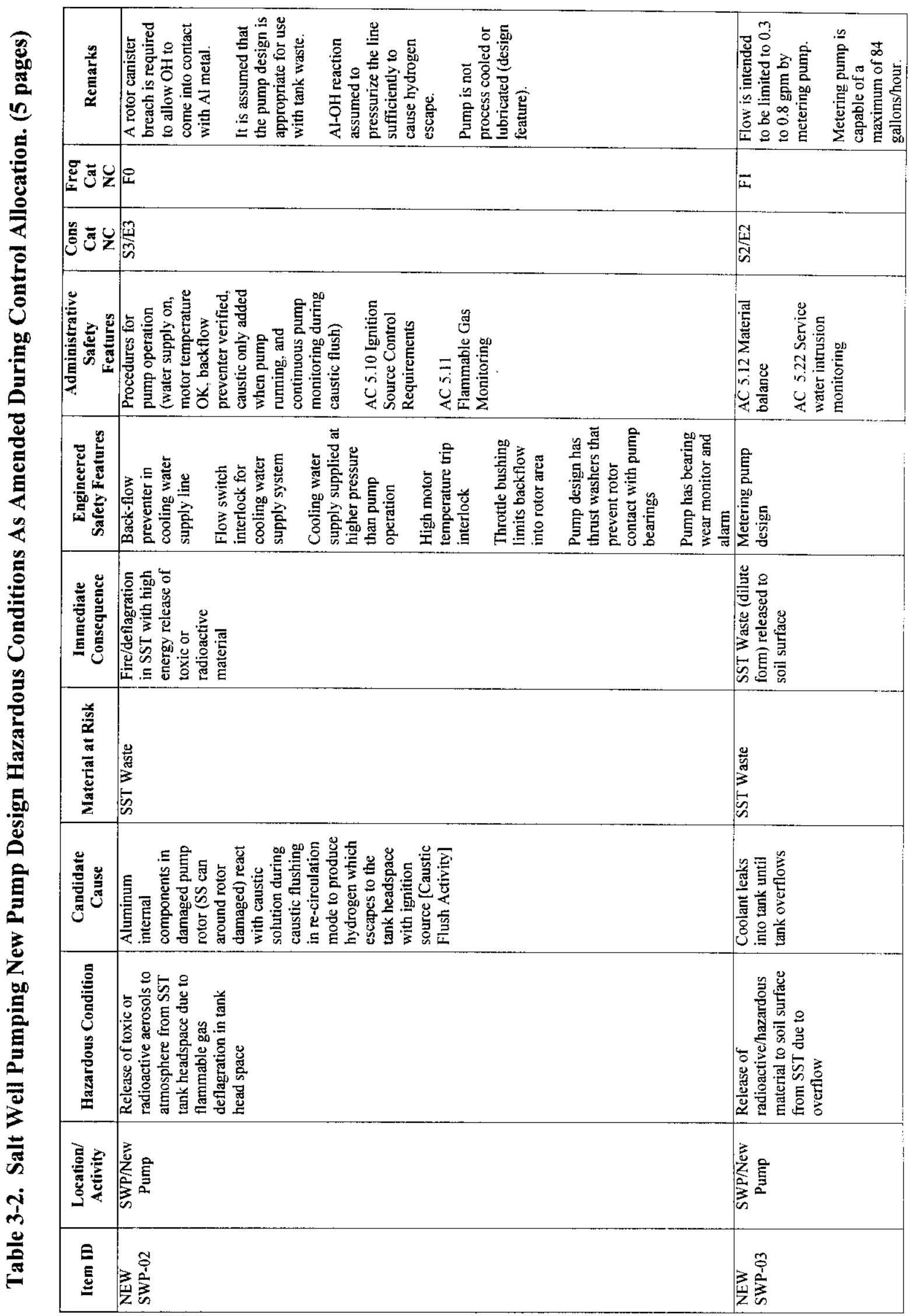


RPP-6954 REV 0

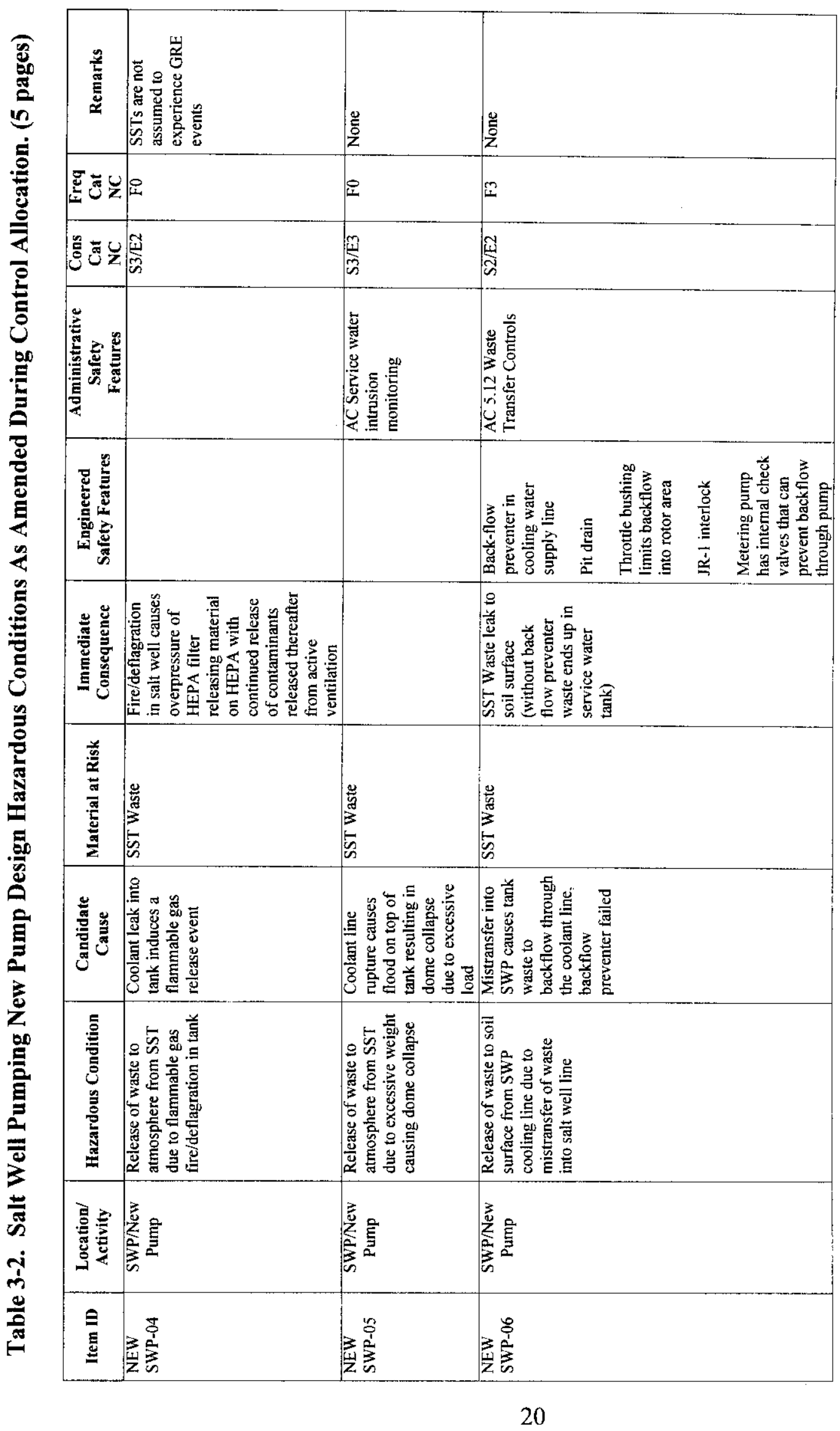




\section{RPP-6954 REV 0}

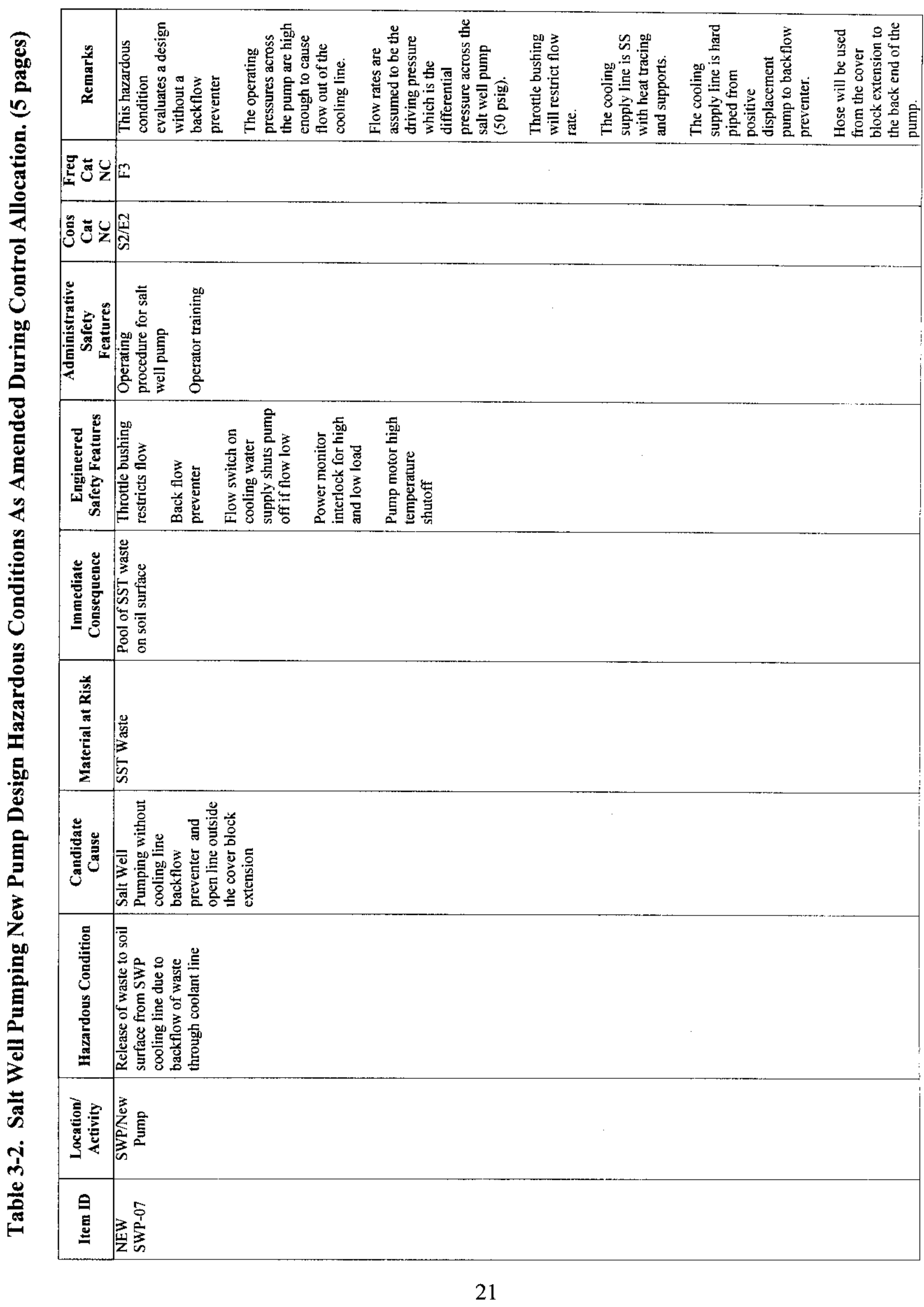




\section{RPP-6954 REV 0}

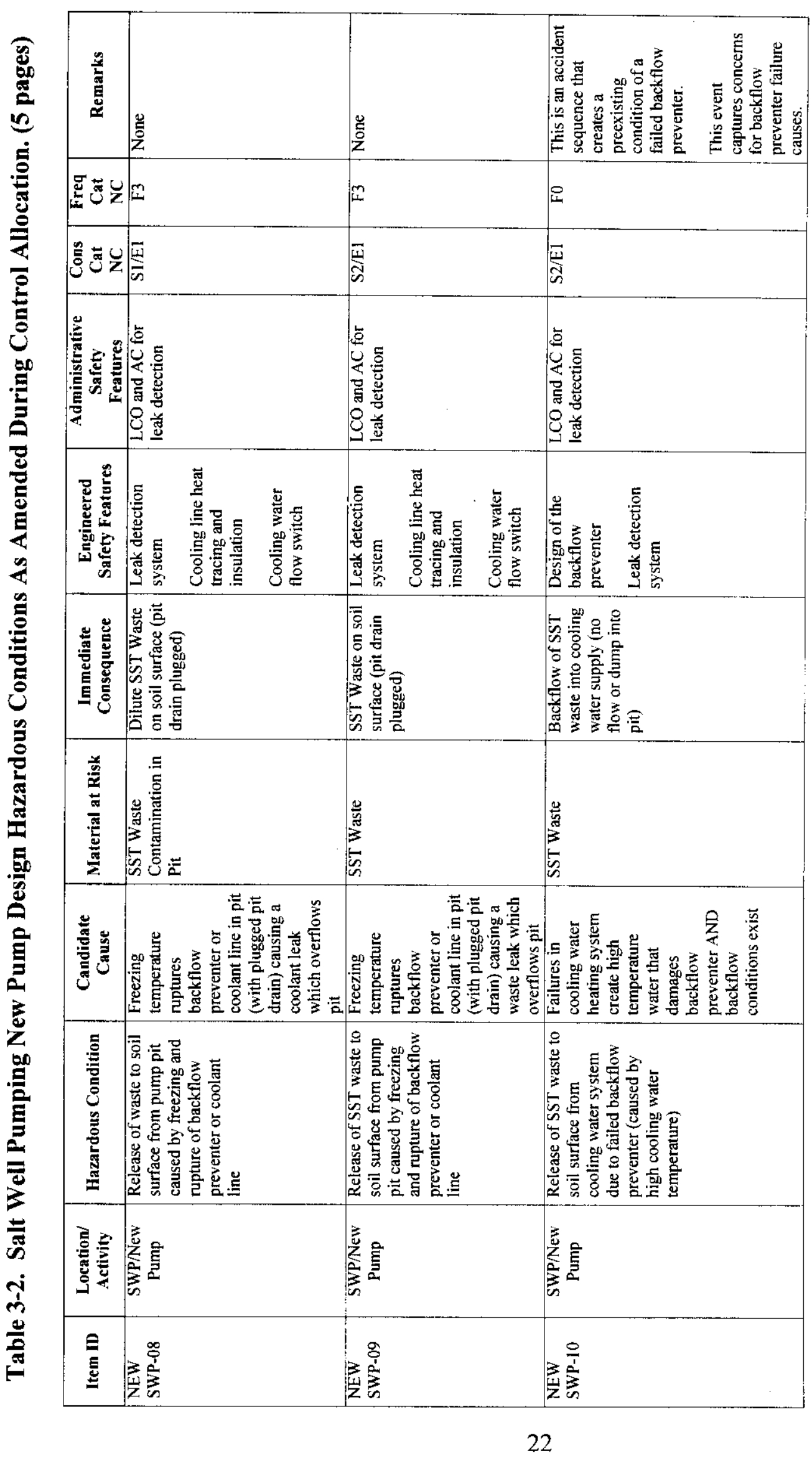


Table 3-3. Salt Well Pumping New Pump Design Hazardous Conditions Sorted According To Consequence.

\begin{tabular}{|c|c|c|c|c|}
\hline Item ID & Hazardous Condition & Cause & $\begin{array}{c}\text { Freq } \\
\text { Cat }\end{array}$ & $\begin{array}{l}\text { Env } \\
\text { Cons }\end{array}$ \\
\hline \multicolumn{5}{|c|}{ Hazardous Conditions with Potentially Significant Facility worker Consequences (S1) } \\
\hline $\begin{array}{l}\text { NEW } \\
\text { SWP-08 }\end{array}$ & $\begin{array}{l}\text { Release of waste to soil surface } \\
\text { from pump pit caused by freezing } \\
\text { and rupture of backflow preventer } \\
\text { or coolant line }\end{array}$ & $\begin{array}{l}\text { Freezing temperature ruptures } \\
\text { backflow preventer or coolant line in } \\
\text { pit (with plugged pit drain) causing a } \\
\text { coolant leak which overflows pit }\end{array}$ & $\mathrm{F} 3$ & E1 \\
\hline \multicolumn{5}{|c|}{ Hazardous Conditions with Potentially Significant On-site Worker Consequences (S2) } \\
\hline $\begin{array}{l}\text { NEW } \\
\text { SWP-01 }\end{array}$ & $\begin{array}{l}\text { Release of toxic or radioactive } \\
\text { aerosols to atmosphere from SST } \\
\text { pump pit due to flammable gas } \\
\text { deflagration in pit }\end{array}$ & $\begin{array}{l}\text { Aluminum internal components in } \\
\text { damaged pump rotor (SS can around } \\
\text { rotor damaged) react with caustic } \\
\text { solution during caustic flushing in } \\
\text { recirculation mode to produce } \\
\text { hydrogen which escapes to the pit } \\
\text { with ignition source [Caustic Flush } \\
\text { Activity] }\end{array}$ & F2 & E2 \\
\hline $\begin{array}{l}\text { NEW } \\
\text { SWP-03 }\end{array}$ & $\begin{array}{l}\text { Release of radioactive/hazardous } \\
\text { material to soil surface from SST } \\
\text { due to overflow }\end{array}$ & $\begin{array}{l}\text { Coolant leaks into tank until tank } \\
\text { overflows }\end{array}$ & F1 & E2 \\
\hline $\begin{array}{l}\text { NEW } \\
\text { SWP-06 }\end{array}$ & $\begin{array}{l}\text { Release of waste to soil surface } \\
\text { from SWP cooling line due to } \\
\text { mistransfer of waste into salt well } \\
\text { line }\end{array}$ & $\begin{array}{l}\text { Mistransfer into SWP causes tank } \\
\text { waste to backflow through the coolant } \\
\text { line, backflow preventer failed }\end{array}$ & F3 & E2 \\
\hline $\begin{array}{l}\text { NEW } \\
\text { SWP-07 }\end{array}$ & $\begin{array}{l}\text { Release of waste to soil surface } \\
\text { from SWP cooling line due to } \\
\text { backflow of waste through coolant } \\
\text { line }\end{array}$ & $\begin{array}{l}\text { Salt Well Pumping without cooling } \\
\text { line backflow preventer and open line } \\
\text { outside the cover block extension }\end{array}$ & F3 & E2 \\
\hline $\begin{array}{l}\text { NEW } \\
\text { SWP-09 }\end{array}$ & $\begin{array}{l}\text { Release of SST waste to soil surface } \\
\text { from pump pit caused by freezing } \\
\text { and rupture of backflow preventer } \\
\text { or coolant line }\end{array}$ & $\begin{array}{l}\text { Freezing temperature ruptures } \\
\text { backflow preventer or coolant line in } \\
\text { pit (with plugged pit drain) causing a } \\
\text { waste leak which overflows pit }\end{array}$ & F3 & $\mathrm{E} 2$ \\
\hline $\begin{array}{l}\text { NEW } \\
\text { SWP-10 }\end{array}$ & $\begin{array}{l}\text { Release of SST waste to soil surface } \\
\text { from cooling water system due to } \\
\text { failed backflow preventer (caused } \\
\text { by high cooling water temperature) }\end{array}$ & $\begin{array}{l}\text { Failures in cooling water heating } \\
\text { system create high temperature water } \\
\text { that damages backflow preventer } \\
\text { AND backflow conditions exist }\end{array}$ & F0 & E2 \\
\hline \multicolumn{5}{|c|}{ Hazardous Conditions with Potentially Significant Offsite Individual Consequences (S3) } \\
\hline $\begin{array}{l}\text { NEW } \\
\text { SWP-02 }\end{array}$ & $\begin{array}{l}\text { Release of toxic or radioactive } \\
\text { aerosols to atmosphere from SST } \\
\text { tank headspace due to flammable } \\
\text { gas deflagration in tank head space }\end{array}$ & $\begin{array}{l}\text { Aluminum internal components in } \\
\text { damaged pump rotor (SS can around } \\
\text { rotor damaged) react with caustic } \\
\text { solution during caustic flushing in } \\
\text { recirculation mode to produce } \\
\text { hydrogen which escapes to the tank } \\
\text { headspace with ignition source } \\
\text { [Caustic Flush Activity }\end{array}$ & F0 & E3 \\
\hline $\begin{array}{l}\text { NEW } \\
\text { SWP-04 }\end{array}$ & $\begin{array}{l}\text { Release of waste to atmosphere } \\
\text { from SST due to flammable gas } \\
\text { fire/deflagration in tank }\end{array}$ & $\begin{array}{l}\text { Coolant leak into tank induces a } \\
\text { flammable gas release event }\end{array}$ & F0 & E3 \\
\hline $\begin{array}{l}\mathrm{NEW} \\
\text { SWP-05 }\end{array}$ & $\begin{array}{l}\text { Release of waste to atmosphere } \\
\text { from SST due to excessive weight } \\
\text { causing dome collapse }\end{array}$ & $\begin{array}{l}\text { Coolant line rupture causes flood on } \\
\text { top of tank resulting in dome collapse } \\
\text { due to excessive load }\end{array}$ & F0 & E3 \\
\hline
\end{tabular}


RPP-6954 REV 0

This page intentionally left blank. 
RPP-6954 REV 0

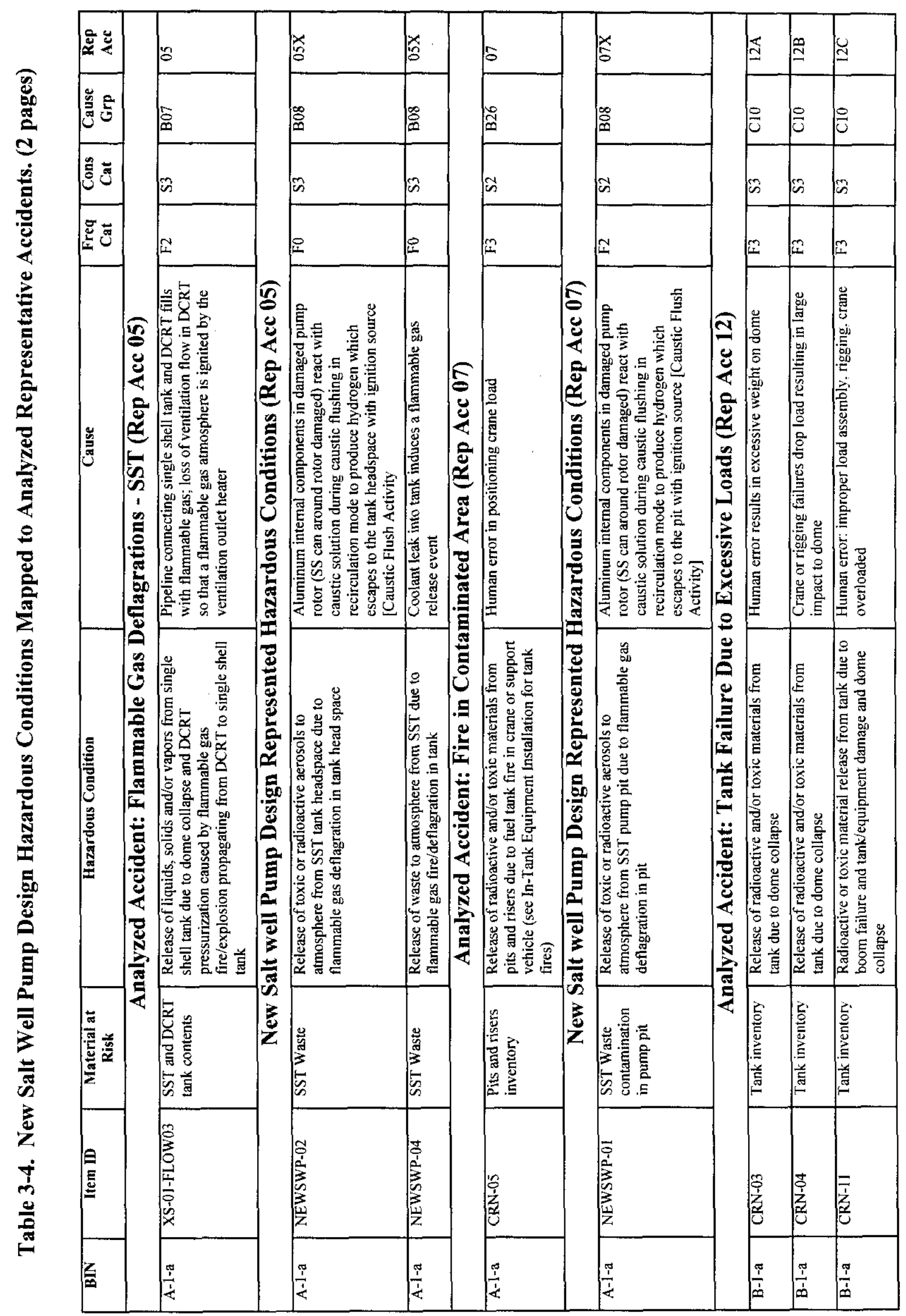




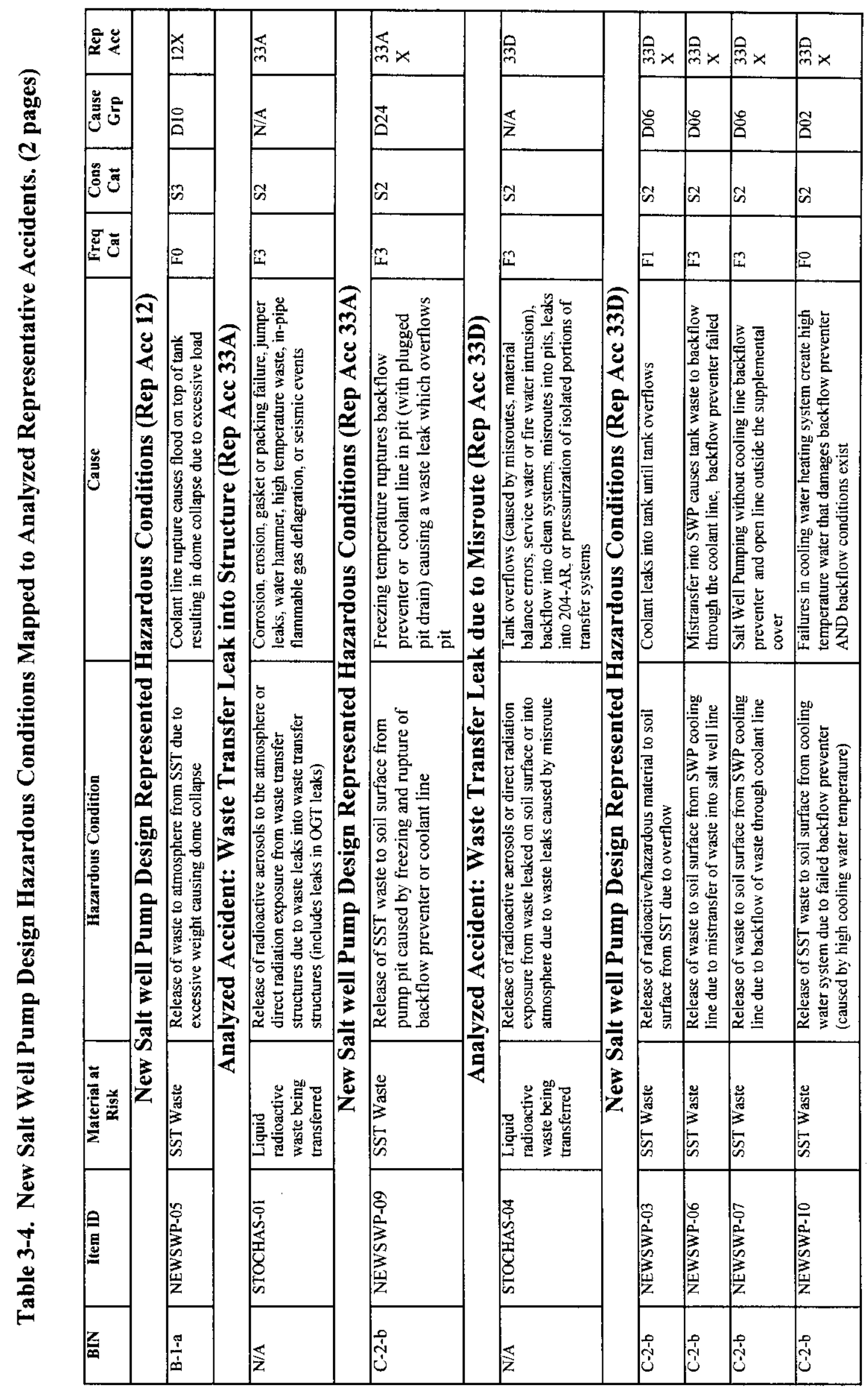


RPP-6954 REV 0

\subsection{CONTROL ALLOCATION}

\subsection{METHODOLOGY}

The control decision/allocation team first considered the results of the PHA. Prior to the meeting, the hazardous conditions identified during the PHA meeting were evaluated and then mapped to existing analyzed accidents. From this mapping, a suite of proposed controls was identified. This information was then reviewed for accuracy, with changes incorporated as necessary. The team then reviewed the proposed $\mathrm{AB}$ controls. Consensus was reached to determine if controls were adequate to prevent or mitigate the identified potential hazardous conditions or might introduce new hazards.

If existing controls were determined to adequately address the hazardous condition, the applicable controls were selected. If existing controls are not sufficient or inadequate for any reason, the control decision/allocation team proposed new or modified controls.

\subsection{ALLOCATED CONTROLS}

The results of the control decision/allocation meeting is presented in Table 4-1. The hazardous conditions identified for the new salt well pump are listed in ascending order of the representative accidents. In all but one case, existing controls for the representative accidents were found adequate to prevent or mitigate the hazardous condition. For one hazardous condition related to backflow of waste through the pump motor cooling line, ID \# NEWSWP-07, a backflow preventer was determined to be required as a preventive SSC with a related LCO to ensure operability. 


\section{RPP-6954 REV 0}

This page intentionally left blank. 


\subsection{CONCLUSIONS}

There were 10 hazardous conditions identified specific to the new salt well pump design. Of these, one was a low consequence hazardous condition related to worker exposure to ionizing radiation and minor contamination events (spills or leaks). This is adequately addressed by the Tank Farms Radiation Protection Program.

Of the remainder, the hazardous conditions are related to four representative accidents. There were two hazardous conditions related to Flammable Gas Deflagrations in an SST, one hazardous condition is related to the Fire in Contaminated Area accident, one hazardous condition is related to the Tank Failure Due to Excessive Loads accident, one hazardous condition is related to the Waste Transfer Leak Into Structure accident, and four hazardous conditions are related to the Waste Transfer Leak Due To Misroute accident. In all cases it was determined that the consequences of these hazardous conditions were bounded by the representative accident.

The controls allocated, for all but one hazardous condition, were existing controls currently allocated to the related representative accident. For the remaining hazardous condition, ID \# NEWSWP-07, the control decision/allocation team determined that a backflow preventer was required to prevent a backflow of waste into the pump motor cooling line. The addition of this backflow preventer and a related LCO will require an amendment to the Authorization Basis. 
RPP-6954 REV 0

This page intentionally left blank. 
RPP-6954 REV 0

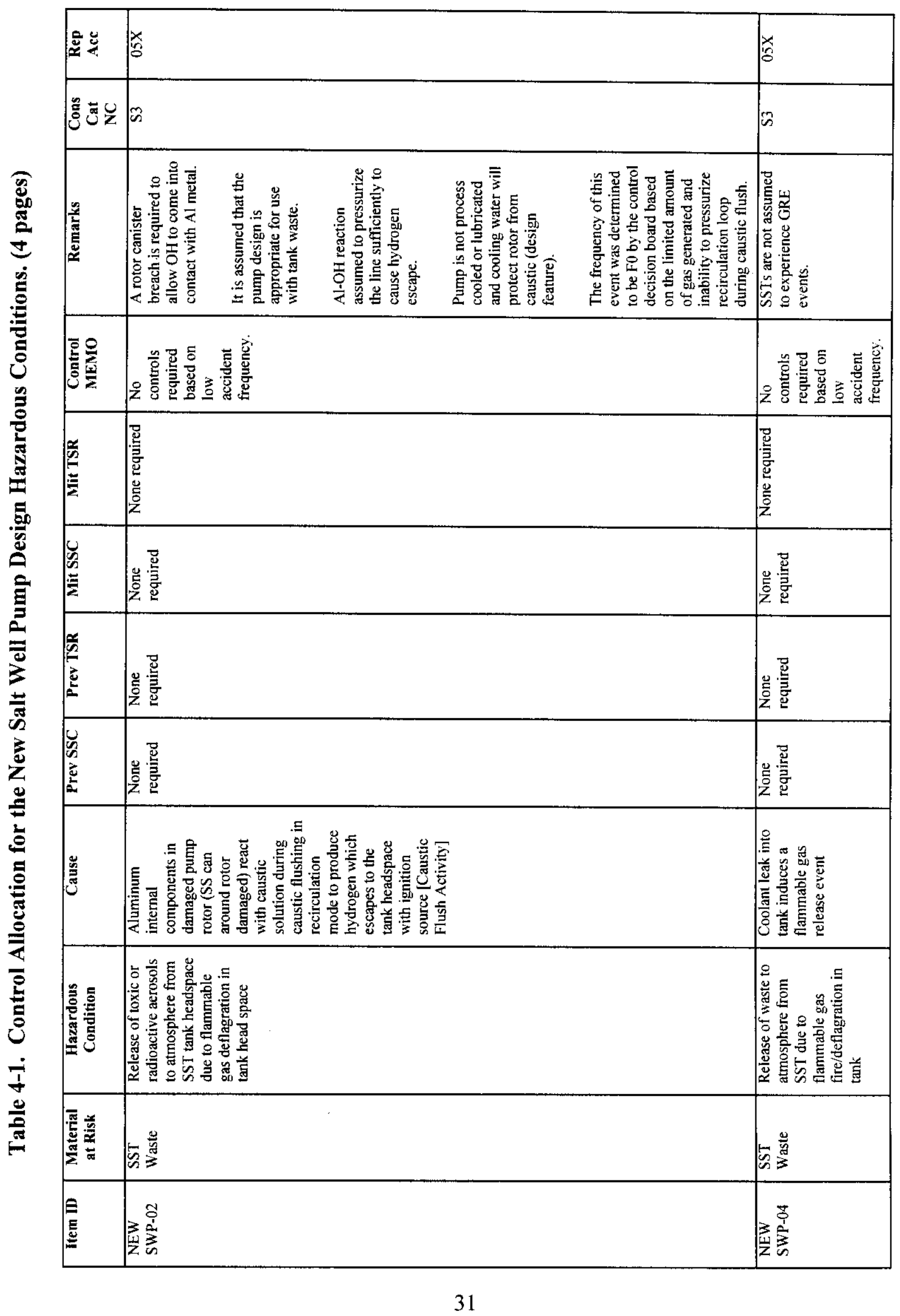


RPP-6954 REV 0

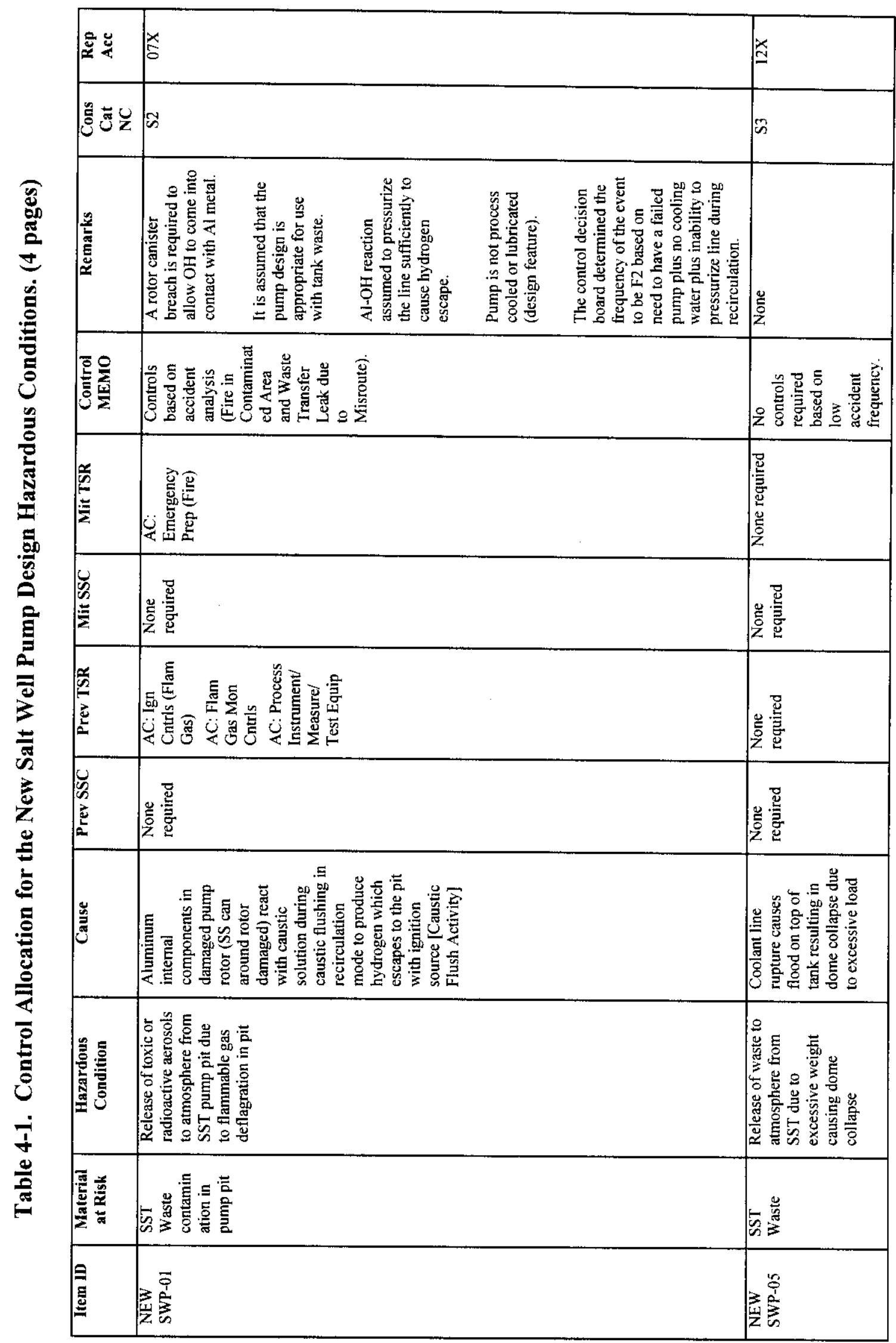


RPP-6954 REV 0

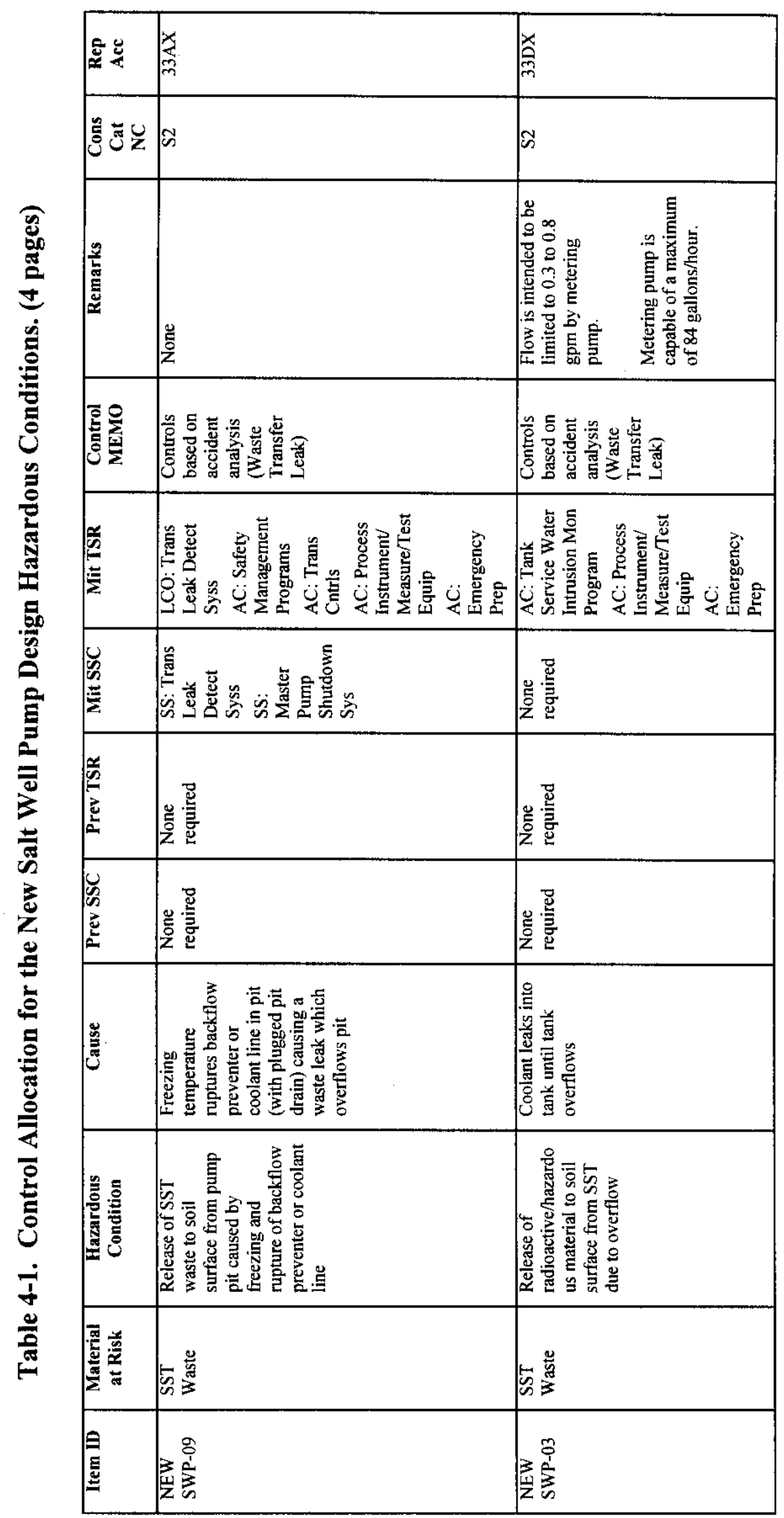




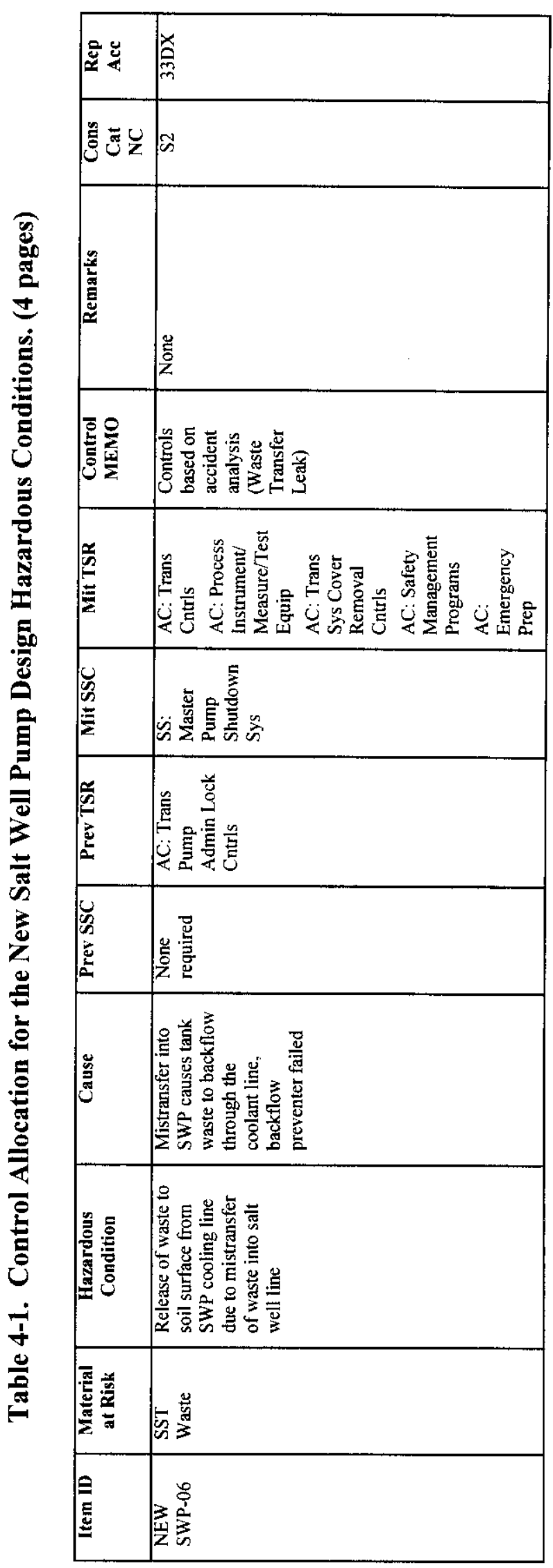


RPP-6954 REV 0

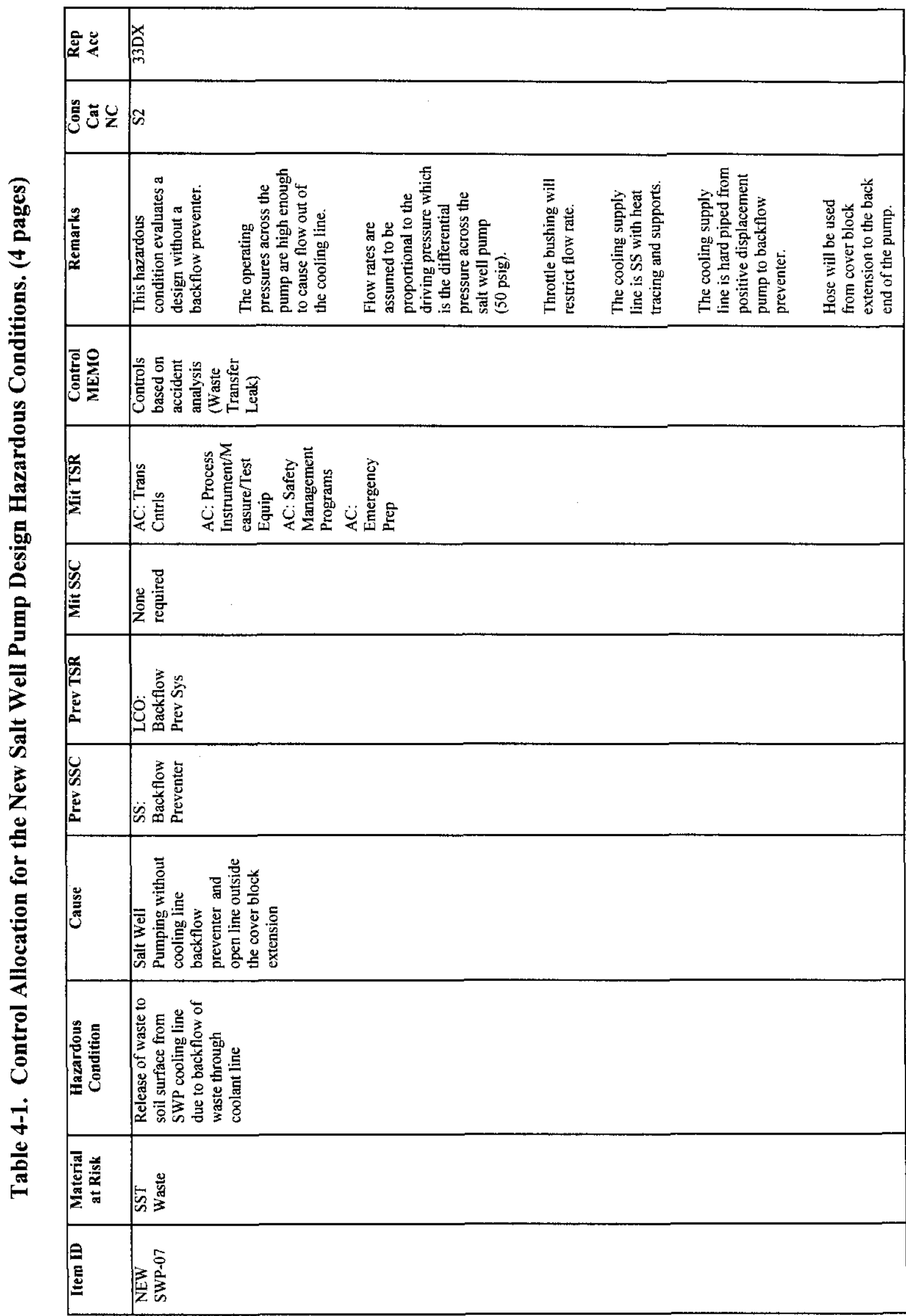


RPP-6954 REV 0

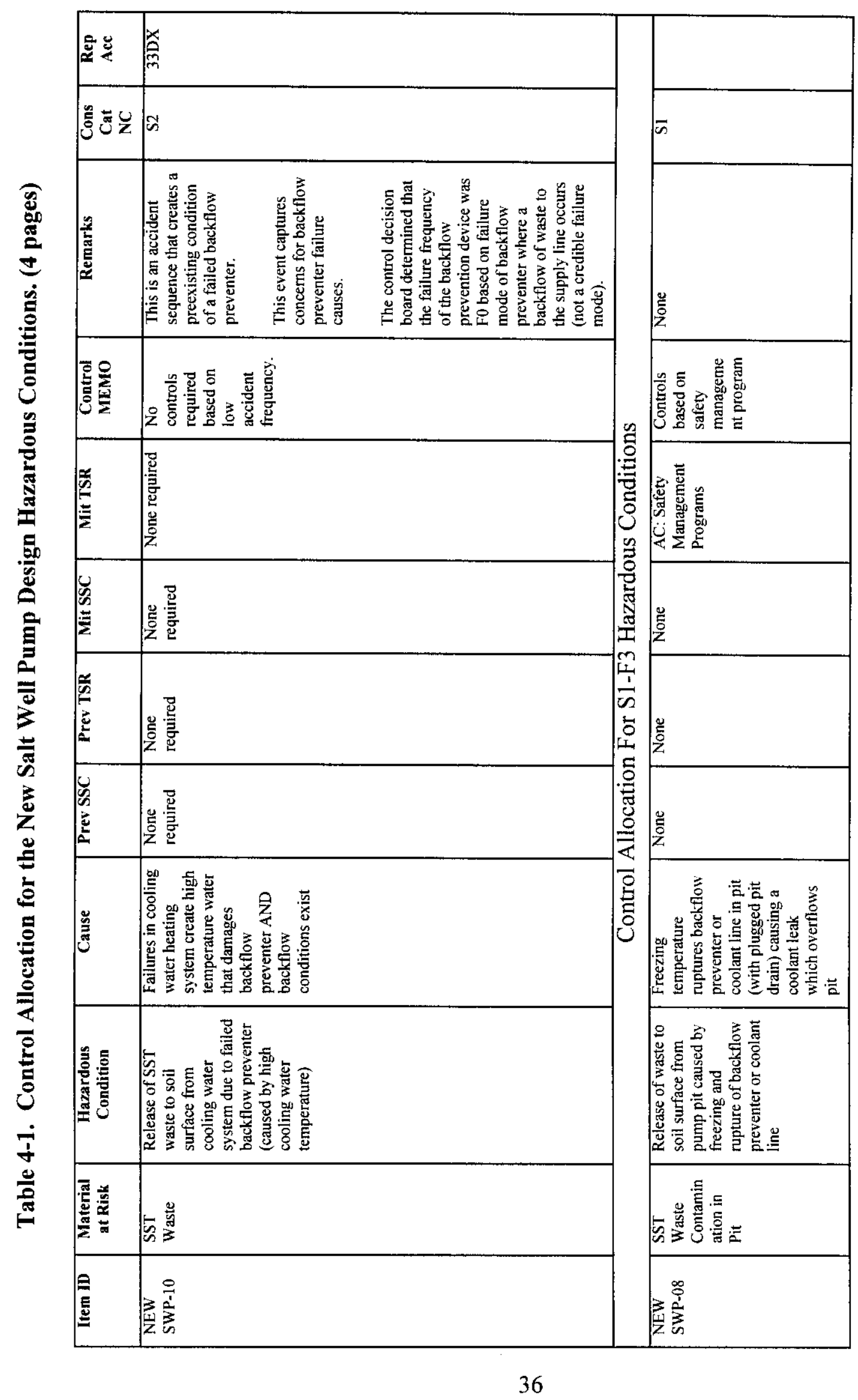




\section{RPP-6954 REV 0}

\subsection{REFERENCES}

CHG 2000a, Tank Waste Remediation System Technical Safety Requirements, HNF-SD-WM-TSR-006, Rev. 1-L, CH2M HILL Hanford Group, Inc., Richland, Washington.

CHG 2000b, Hazard Analysis Database Report, HNF-SD-WM-TI-764, Rev. 2-F, CH2M HILL Hanford Group, Inc., Richland, Washington

CHG 2000c, Tank Waste Remediation System Final Safety Analysis Report, HNF-SD-WM-SAR-067, Rev. 1-M, CH2M HILL Hanford Group, Inc., Richland Washington.

AIChE, 1992, Guidelines for Hazard Evaluation Procedures, American Institute of Chemical Engineers, New York, New York. 


\section{RPP-6954 REV 0}

This page intentionally left blank. 
RPP-6954 REV 0

APPENDIX A

PRELIMINARY HAZARDS ANALYSIS

TEAM BIOGRAPHICAL INFORMATION 
RPP-6954 REV 0

This page intentionally left blank. 


\section{APPENDIX A \\ PRELIMINARY HAZARDS ANALYSIS TEAM BIOGRAPHICAL INFORMATION}

James R. Bellomy III - Cognizant Engineer, Maintenance and Reliability Engineering. Mr. Bellomy has 20 years of engineering experience in design, construction, start-up and testing at both commercial and government owned reactor and non-reactor nuclear facilities. He has over 16 years experience at the Hanford Site supporting numerous Hanford construction projects and facility upgrades at $\mathrm{N}$-Reactor and the 200 Area tank farms. He has experience in all aspects of systems design, fabrication, construction, and testing and has been involved in several hazard evaluations and safety assessments. Mr. Bellomy has been an Unreviewed Safety Question (USQ) Evaluator for the past 6 years and has provided support to several tank waste retrieval projects including tank 241-C-106 waste retrieval, tank 241-AZ-101 mixer pump testing, long length equipment removal, and salt well pumping.

William H. Grams - B.S. Mining Engineering, M.S. Mechanical Engineering. Mr. Grams has more than 20 years of experience in the nuclear industry, all of it with the disposal of high and low-level radioactive waste. He has over 15 years of experience at the Hanford Site including authorization basis (AB) assessments of new activities, accident analysis and release calculations, USQ screening and determinations, hazard assessments, and $\mathrm{AB}$ revisions. Other nuclear related experience includes low-level waste certification, waste management assessments and audits, preparation of characterization requirements for low-level waste, preparation of design requirements for waste tank retrieval systems, and identification of regulatory requirements.

Clifford E. Hampton - A.A. in Science. Mr. Hampton has more than 23 years of experience in the nuclear industry, most is in the Navy Nuclear field. He has over 20 years experience in the maintenance, testing, and operation of nuclear equipment. He was assigned as the Assistant Naval Reactor Representative (DOE oversight) for overhaul of nuclear submarines. He has 3 years of experience at Hanford working in the maintenance and shift operations areas. $\mathrm{He}$ is a certified Shift Manager, a Building Emergency Director and a USQ screener.

Grant W. Ryan, P.E. -- B.S. Physics, B.S. Nuclear Engineering, PE Mechanical Engineering. Ten years experience in nuclear facility safety analysis and general engineering support. Author of numerous documents at Hanford to support safe nuclear facility operations. These have included operating and alarm response procedures, safety analysis reports Tank Waste Remediation System Basis for Interim Operations (BIO), and the Final Safety Analysis Report (FSAR), calculation notes, topical reports, and engineering studies. 
Milton V. Shultz Jr. - Fluor Federal Services Inc., Safety Analysis and Risk Assessment. B.S. Nuclear Engineering Technology. Scribe for salt well pump Process Hazard Analysis (PHA). More than 26 years experience in a broad range of engineering and technical assignments at the Hanford Site. Experience includes leading PHAs and HAZOPs for a variety of River Protection Project facilities, including several for the FSAR and BIO efforts, contributor to the hazards analysis work for the FSAR. Has performed independent nuclear safety evaluations of reactor plant design and operation at Hanford $\mathrm{N}$ Reactor.

Ryan D. Smith - B.S. Mechanical Engineering. Six years of experience at the Hanford Site with the last three years specific to Nuclear Safety and Licensing (NS\&L) support. NS\&L Engineer for the Interim Stabilization, Characterization, and Vadose Zone programs. Extensive knowledge in flammable gas related issues related to pumping waste to and from tank farm facilities. Key team member in establishing the $\mathrm{AB}$ for Interim Stabilization and reconciliation of the Los Alamos National Laboratory Safety Assessment with the BIO. Assisted in the transition of the BIO to the FSAR as well as ongoing $\mathrm{AB}$ maintenance and clarification support.

Michael A. White - B.S. in Mechanical Engineering. Mr. White has over 8 years of experience in the nuclear industry, all with the storage, treatment, handling, and transfer of radioactive liquid waste at the Hanford Site. His responsibilities have been focused in support of facility operations, including facility modification/upgrades, testing, and startup. Mr. White assisted in the development of the 242-A Evaporator/Liquid Effluent Retention Facility Safety Analysis Report, Safety Equipment List, and Part B Permit application, and has experience as a core USQ Evaluator.

William F. Zuroff - B.S. Degree, University of Idaho, Mr. Zuroff has more than 30 years of experience in the nuclear industry including nuclear operations, instrument maintenance, and plant engineering. He has over 15 years experience at the Hanford Site including equipment design, testing, operations, and USQ evaluations. Other nuclear related experience includes preparation of design requirements, and procurement specifications for nuclear monitoring systems. 
RPP-6954 REV 0

\section{APPENDIX B}

CONTROL ALLOCATION TEAM

BIOGRAPHICAL INFORMATION 


\section{RPP-6954 REV 0}

This page intentionally left blank. 


\section{APPENDIX B \\ CONTROL ALLOCATION TEAM BIOGRAPHICAL INFORMATION}

James R. Bellomy III - Cognizant Engineer, Maintenance and Reliability Engineering. Mr. Bellomy has 20 years of engineering experience in design, construction, start-up and testing at both commercial and government owned reactor and non-reactor nuclear facilities. He has over 16 years experience at the Hanford Site supporting numerous Hanford construction projects and facility upgrades at N-Reactor and the 200 Area tank farms. He has experience in all aspects of systems design, fabrication, construction, and testing and has been involved in several hazard evaluations and safety assessments. Mr. Bellomy has been an Unreviewed Safety Question (USQ) Evaluator for the past 6 years and has provided support to several tank waste retrieval projects including tank 241-C-106 waste retrieval, tank 241-AZ-101 mixer pump testing, long length equipment removal, and salt well pumping.

William H. Grams - B.S. Mining Engineering, M.S. Mechanical Engineering. Mr. Grams has more than 20 years of experience in the nuclear industry, all of it with the disposal of high and low-level radioactive waste. He has over 15 years of experience at the Hanford Site including authorization basis (AB) assessments of new activities, accident analysis and release calculations, USQ screening and determinations, hazard assessments, and AB revisions. Other nuclear related experience includes low-level waste certification, waste management assessments and audits, preparation of characterization requirements for low-level waste, preparation of design requirements for waste tank retrieval systems, and identification of regulatory requirements.

Gregory L. Jones - Mr. Jones has over 23 years of experience in activities related to the safety of nuclear facilities. He has experience in nuclear plant licensing/safety evaluations (Probabilistic Risk Assessment (PRA) and deterministic), nuclear fuels reprocessing facility safety assessment, and plant/facility design and operational review. Areas of specialization in safety and licensing include: Safety Analysis Report (SAR) and Technical Specification/Operational Safety Requirements preparation for both nuclear power plants and fuels reprocessing facilities; USQ screenings and determinations; release and transport of radioactivity during normal, abnormal and accident conditions; evaluation of containment/confinement system capabilities for nonreactor risk assessment; dose consequence evaluations; natural forces design and accident evaluations; accident analysis, fault tree modeling, uncertainty/sensitivity analysis using CAFTA; and application of human reliability analysis. Other areas of specialization include project planning, program management engineering, peer review of PRA and deterministic analysis; and applied above specialties to over 20 Boiler Water Reactor and Pressurized Water Reactor FSAR updates. 


\section{RPP-6954 REV 0}

Lawrence J. Kripps - B.S. and M.S. Nuclear Engineering. Over twenty-six years experience managing and performing safety analyses and environmental assessments of U.S. Department of Energy and commercial nuclear and non-nuclear facilities. Provided technical direction and support in the development of the hazard and accident analyses and controls for the and FSAR and the associated Technical Safety Requirements.

David J. Saueressig - B.S. in Mechanical Engineering. Mr. Saueressig has more than 13 years of experience in the nuclear industry, all of it with the storage, handling, and transfer of radioactive liquid waste. He has 13 years of experience at the Hanford Site including assignments in Process Engineering and Shift Operations Management. He is a certified Shift Manager within RPP, is a Building Emergency Director, and USQ screener. He has spent six years on shift as a supervisor/manager supporting operations, including salt well pumping.

Ryan D. Smith - B.S. Mechanical Engineering. Six years of experience at the Hanford Site with the last three years specific to Nuclear Safety and Licensing (NS\&L) support. NS\&L Engineer for the Interim Stabilization, Characterization, and Vadose Zone programs. Extensive knowledge in flammable gas related issues related to pumping waste to and from tank farm facilities. Key team member in establishing the Authorization Basis (AB) for Interim Stabilization and reconciliation of the Los Alamos National Laboratory Safety Assessment with the BIO. Assisted in the transition of the BIO to the FSAR as well as ongoing AB maintenance and clarification support.

Michael A. White - B.S. in Mechanical Engineering. Mr. White has over 8 years of experience in the nuclear industry, all with the storage, treatment, handling and transfer of radioactive liquid waste at the Hanford Site. His responsibilities have been focused in support of facility operations, including facility modification/upgrades, testing, and startup. Mr. White assisted in the development of the 242-A Evaporator/Liquid Effluent Retention Faciity Safety Analysis Report, Safety Equipment List, and Part B Permit application, and has experience as a core USQ Evaluator.

William F. Zuroff - B.S. Degree University of Idaho. Mr. Zuroff has more than 30 years of experience in the nuclear industry including nuclear operations, instrument maintenance and plant engineering. He has over 15 years experience at the Hanford Site including equipment design, testing, operations, and USQ evaluations. Other nuclear related experience includes preparation of design requirements, and procurement specifications for nuclear monitoring systems. 


\begin{tabular}{|c|c|c|c|}
\hline \multicolumn{4}{|c|}{ Control Decision Meeting Attendance } \\
\hline Name & \begin{tabular}{|c|} 
Knowledge Area(s) \\
Represented (see below)
\end{tabular} & Organization & $\begin{array}{l}\text { Telephone } \\
\text { Number } \\
\end{array}$ \\
\hline Willomitt & $1,2,3,8,15,16,17$ & $N \leq 24$ & $373-7308$ \\
\hline & $1,239,9,15,16,7$ & NSOL & $373-325$ \\
\hline Lnwresnce & 15,6 & NSTC & $376-1061$ \\
\hline williame t. tweofp & $3,10,15^{\prime}$ & $15 \times 00$ & $33-1003$ \\
\hline Bellomy, TAmes R & $3,4,5,14,20$ & $m \in R E$ & $3>2-14 \geq 3$ \\
\hline SAMeressic Davin I & 4,5 & $1 / 5$ ops & 373.0183 \\
\hline$S_{3} \cdot L$, Ran $D$ & 1 & NSTL & $372-1383$ \\
\hline Mine white & $3,4,11,14,15,20$ & TSE & $3-5453$ \\
\hline & & & \\
\hline & & & \\
\hline & & & \\
\hline & & & \\
\hline & & & \\
\hline & & & \\
\hline & & & \\
\hline & & & \\
\hline
\end{tabular}

Knowledge Areas:

1 Licensing Engineer

2 Hazard Analysis

3 Engineering

4 Operations

5 Project Management

6 Quality Assurance

7 Process Engineering
8 Safety Analyst

9 Accident Analysis

10 Design Authority

11 Design Agent

12 Radiological Control

13 Environmental Support

14 Equipment Engineering
15 Safety Structures, Systems, \& Components

16 Technical Safety Requirements

17 Nuclear Safety \& Licensing

18 Safety \& Emergency Preparedness

19 Regulatory Compliance Support

20 Maintenance \& Reliability Engineering

21 Other-Specify 


\section{RPP-6954 REV 0}

This page intentionally left blank. 
RPP-6954 REV 0

APPENDIX C

PRELIMINARY HAZARDS ANALYSIS AND

CONTROL ALLOCATION PEER REVIEW 


\section{APPENDIX C}

\section{PRELIMINARY HAZARDS ANALYSIS AND CONTROL ALLOCATION PEER REVIEW}

Practice 1342901112

Publication Date 22Nov99

Attachment 02 - Sheet 1 of 1

\section{FLUOR DANIEL NORTHWEST}

\section{TECHNICAL PEER REVIEWS}

\section{CHECKLIST FOR TECHNICAL PEER REVIEW}
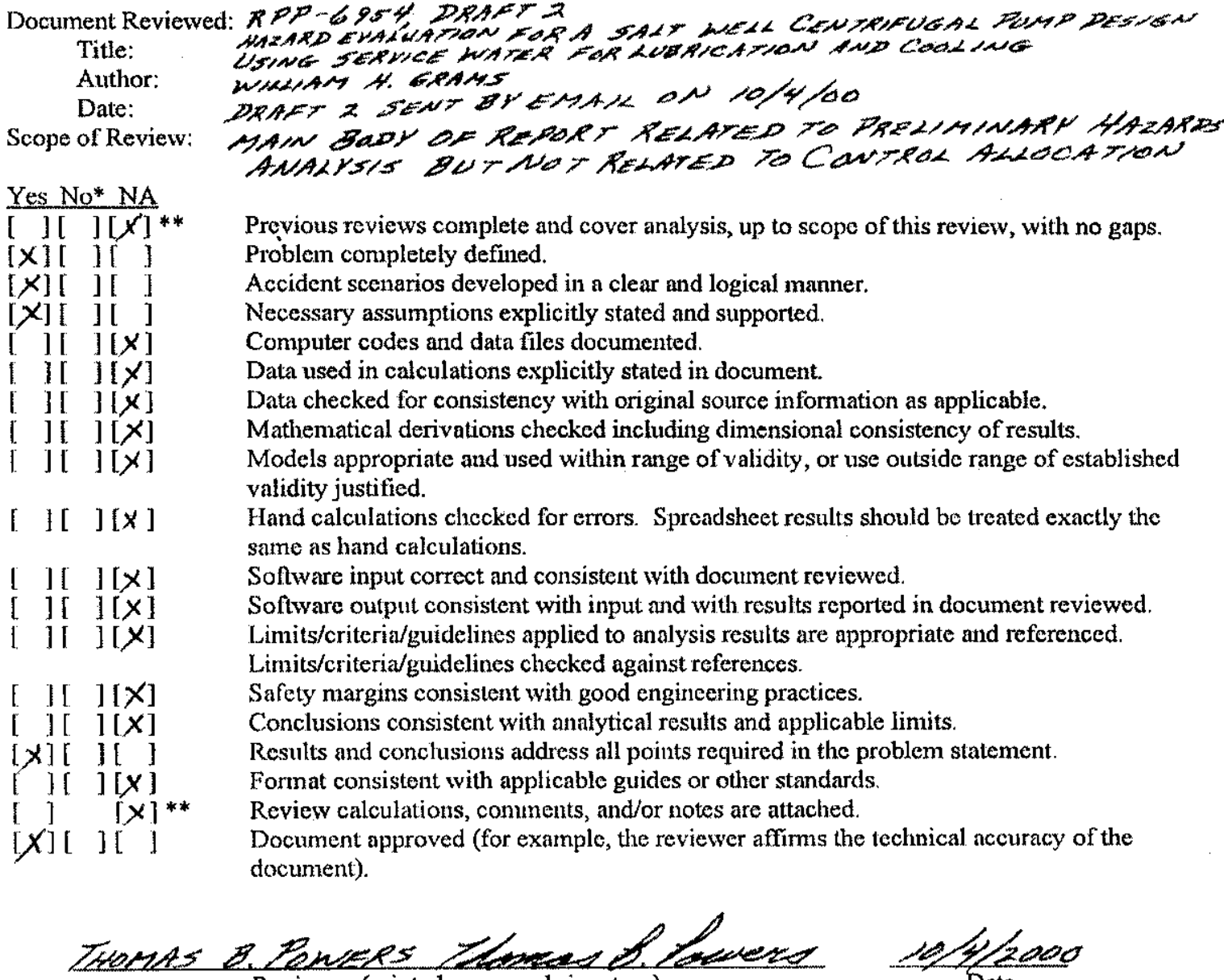

Reviewer (printed name and signature)

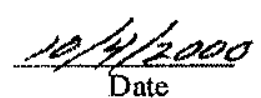

* All "no" responses must be explained below or on an additional sheet.

** Any calculations, comments, or notes generated as part of this review should be signed, dated, and attached to this checklist. The material should be labeled and recorded in such a manner as to be intelligible to a technically qualified third party. 